\title{
Stalking Secret Law: What Predicts Publication in the United States Courts of Appeals
}

Nearly four out of every five federal court of appeals opinions are unpublished. For more than twenty-five years, judges and scholars have debated the wisdom and fairness of this body of "secret" law. The debate over unpublished opinions recently intensified when the Eighth Circuit held that the Constitution requires courts to give these opinions precedential value. Despite continuing controversy over the role of unpublished opinions in the federal system, limited empirical evidence exists on the nature of those opinions. Working with an especially complete dataset of labor law opinions and using multivariate statistical methods, Professors Merritt and Brudney were able to identify numerous factors associated with publication. Some of those factors, such as a decision to reverse the agency, track formal publication rules. Others, such as the number of judges on the panel who graduated from elite law schools or the number with expertise in the disputed subject, are more surprising. Merritt and Brudney also discovered substantial evidence of partisan disagreement within unpublished opinions, suggesting that those cases are not as routine as publication rules seem to assume. These empirical findings should guide constitutional and policy deliberations about the future of unpublished opinions. 



\title{
Stalking Secret Law: What Predicts Publication in the United States Courts of Appeals
}

\author{
Deborah Jones Merritt* \\ James J. Brudney"
}

INTRODUCTION ............................................................72

I. LIMTTED PUBLICATION IN THE COURTS OF APPEALS ............75

II. THE DATABASE ..........................................................79

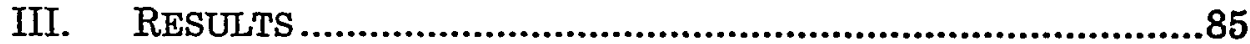

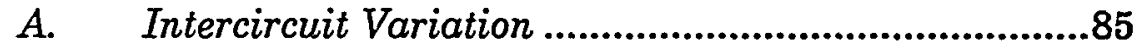

B. Case Characteristics and Issues.............................91

C. Panel Characteristics.............................................94

D. Strategic Behavior .................................................97

E. Homogeneous Panels and Whistleblower Effects.....103

F. $\quad$ Are Unpublished Opinions Routine?.......................107

IV. DISCUSSTON ...................................................................111

A. $\quad$ Support for Limited Publication Rules ....................111

B. Warning Signals................................................112

C. Should Unpublished Opinions Be Precedential?.....118

CONCLUSION....................................................................121

* John Deaver Drinko/Baker \& Hostetler Chair in Law, The Ohio State University; Director, The John Glenn Institute for Public Service and Public Policy; Fellow, Center for Law, Policy, and Social Science, The Ohio State University College of Law. We thank Lawrence Baum, Douglas Berman, Gregory Caldeira, Ruth Colker, Corey Ditslear, Lowell Hargens, Alan Michaels, Michael Solimine, and participants at workshops sponsored by the Northwestern University School of Law and Ohio State's Center for Law, Policy, and Social Science for their helpful comments. The Fund for Labor Relations Studies provided financial support for this project:

Professor of Law, The Ohio State University; Director, Center for Law, Policy, and Social Science, The Ohio State University College of Law. 


\section{INTRODUCTION}

For more than a quarter century, the United States Courts of Appeals have maintained two bodies of law. One is published, widely disseminated, and fully precedential. The other, now encompassing nearly $80 \%$ of all dispositions on the merits, ${ }^{1}$ is unpublished, erratically distributed, and rarely precedential. ${ }^{2}$ What distinguishes these two sets of cases? Is it possible to predict why judges publish opinions in some cases while resolving others through unpublished opinions, memoranda, or judgment orders?

Each court has formal rules governing the publication of opinions, but those standards fail to account for variations in publication. Despite substantial overlap among circuit rules, publication rates differ widely among courts and even among individual judges. In 1999, the Fourth Circuit published opinions in only $9.9 \%$ of cases disposed of on the merits, while the First Circuit published opinions in 54.6\%. ${ }^{3}$ Chief Judge Richard Posner of the Seventh Circuit published 181 majority opinions during a recent two-year period, while several judges from other circuits published fewer than twenty majority opinions apiece during the same years. ${ }^{4}$ Differences in caseload are unlikely to explain such dramatic variations in publication rates; judges and circuits seem to differ in the type of cases they find worthy of publication.

Evaluations of the fairness of limited publication rules diverge as markedly as publication rates themselves. Many judges

1. According to figures released by the Administrative Office of the United States Courts, the courts of appeals resolved 26,727 cases on the merits during the year ending September 30 , 1999. JUDICIAL BUSINESS OF THE UNITED STATES COURTS: 1999 ANNUAL REPORT OF THE DIRECTOR 49 tbl. S-3 (2000), available at http://www.uscourts.gov/judbus1999/s03sep99.pdf [hereinafter 1999 ANNUAL REPORT]. Only 5,371 of those dispositions generated a signed, published opinion; 461 yielded an unsigned published opinion; and nine produced a brief published statement that did not detail the panel's reasoning. Id. Fully $78.1 \%$ of the courts' merits dispositions were unpublished. Id. The largest category of these unpublished dispositions $(15,528)$ were "written, reasoned, unsigned" opinions or memoranda; 3,951 were "written, signed" opinions; 1,290 were "written, unsigned [judgments], without comment"; and 117 were oral. Id. All of theso figures exclude the Court of Appeals for the Federal Circuit. The 78.1\% figure reflects a steady increase in the proportion of unpublished merits dispositions since the late 1970s. See infra notos 16-18 and accompanying text.

2. Judge Wald eloquently summed up the second-class status of cases decided by unpub. lished disposition: They "will likely receive a few sentences of rationale with maybe a citation or two; they will be memorialized, if at all, only in computer data banks, rather than in the red, gold, and black volumes of the Federal Reporter; they cannot be cited as authority for any propo. sition, rendering them in effect a class of legal 'untouchables.' " Patricia M. Wald, The Rhetoric of Results and the Results of Rhetoric: Judicial Writings, 62 U. CHI. L. REV. 1371, 1373 (1995).

3. See 1999 ANNUAL REPORT, supra note 1, at 49 tbl. S-3.

4. See Mitu Gulati \& C.M.A. McCauliff, On Not Making Law, 61 LAW \& ConTEMP. ProBS. 157,200 (1998). 
and scholars laud the rules as preserving judicial energy, coping creatively with an overwhelming caseload, and reducing the crush of precedent. ${ }^{5}$ Critics, on the other hand, charge that unpublished opinions reduce judicial accountability, deprive litigants of useful precedent, and create incentives for strategic behavior by judges. ${ }^{6}$ Even after twenty-five years, debate remains heated over the role of unpublished opinions in the federal system. ${ }^{7}$

That debate has become especially compelling in light of a recent decision by the Eighth Circuit, holding that Article III of the Constitution requires federal courts to give unpublished opinions precedential weight. ${ }^{8}$ The Eighth Circuit's ruling does not forbid the practice of withholding some opinions from formal publication, ${ }^{9}$ but

5. See generally Boyce F. Martin, Jr., In Defense of Unpublished Opinions, 60 OHIO ST. L.J. 177 (1999); Philip Nichols, Jr., Selective Publication of Opinions: One Judge's View, 35 As. U. L. REv. 909 (1986); Philip Shuchman \& Alan Gelfand, The Use of Local Rule 21 in the Fifth Circuit: Can Judges Select Cases of 'No Precedential Value' ?, 29 EMORY L.J. 195 (1980); Elizabeth MI. Horton, Comment, Selective Publication and the Authorily of Precedent in the United Slates Courts of Appeals, 42 UCLA L. REV. 1691 (1995). Professors Berman and Cooper recently argued that unpublished opinions play a valuable role in allowing panels to explore the implications of new legal doctrines before adopting settled rules. See Douglas A. Berman \& Jefirey O. Cooper, In Defense of Less Precedential Opinions: A Reply to Chief Judge Marlin, 60 OHo ST. L.J. 2025, 2040-41 (1999).

6. See Martha J. Dragich, Will the Federal Courts of Appeals Perish if They Publish? Or Does the Declining Use of Opinions to Explain and Justify Judicial Decisions Pose a Greater Threat?, 44 AN. U. L REv. 757, 785.802 (1995); Pamela Foa, Comment, A Snake in the Path of the Law: The Seventh Circuit's Non-Publication Rule, 39 U. PITT. L. REv. 309, 338-40 (1977). See generally Gulati \& McCauliff, supra note 4; William L. Reynolds \& William M. Richman, An Evaluation of Limited Publication in the United Slates Courts of Appeals: The Price of Reform, 48 U. CHI. I. REV. 573 (1981) [hereinafter Reynolds \& Richman, Price of Reform]; William L. Reynolds \& William M Richman, The Non-Precedential Precedent-Limiled Publication and NoCitation Rules in the United States Courts of Appeals, 78 CoLUM. L REv. 1167 (1978) [hereinafter Reynolds \& Richman, Non-Precedential Precedent]; Kirt Shuldberg, Comment, Digilal In/luence: Technology and Unpublished Opinions in the Federal Courts of Appeals, 85 CAL L REV. 543 (1997); Donald R. Songer, Criteria for Publication of Opinions in the U.S. Courts of Appeals: Formal Rules Versus Empirical Reality, 73 JUDICATURE 307, 309 (1990).

7. Many state courts also maintain limited publication plans; several scholars have investigated the scope of those plans. See generally Keith H. Beyler, Selective Publication Rules: An Empirical Study, 21 LoY. U. CHI. L.J. 1 (1989) (discussing the empirical study of both state and federal rules on selective publication); Thomas B. Marvell, State Appellate Court Responses to Caseload Growth, 72 JUDICATURE 282 (1989) (documenting the growing use of unpublished opinions by state courts).

8. Anastasoff v. United States, 223 F.3d 898 (8th Cir. 2000). The court noted that Article III vests only "judicial Power" in the federal courts, U.S. CONST. art. III, $\S 1$, cl. 1, and held that this power necessarily embraces the principle of precedent. Anastasoff, 223 F.3d at 900, 905.

9. Id. at 904 ("The question presented here is not whether opinions ought to be published, but whether they ought to have precedential effect, whether published or not." $)$. Indeed, the court noted that "limited publication of judicial decisions was the rule" at the time the Constitution was ratified. Id. at 903.

Nor did the Eighth Circuit rule that precedents can never be overruled. See id. at 904. On the contrary, the court confirmed that "[c]ases can be overruled. Sometimes they should be." Id. The court, however, pointed out that overruling a precedent requires "a burden of justification" with 
it raises profound questions about the place of these opinions in our jurisprudence. While we do not explore here the constitutional issues raised by the Eighth Circuit, we report empirical results that provide important background to the debate.

In the past, the elusiveness of unpublished opinions has hampered empirical investigation of their function. Specialized services and electronic databases disseminate some unpublished decisions, but their collections are incomplete. Without a full inventory, it is difficult to explore the differences between unpublished dispositions and their published counterparts. The Administrative Office of the United States Courts collects statistics about published and unpublished dispositions in the federal courts, but those numbers conceal important differences among cases and circuits. For example, one circuit may have a low publication rate because it handles a large number of social security or habeas corpus appeals, cases frequently decided without published opinion.

Appeals from decisions of the National Labor Relations Board ("NLRB") offer a way out of this dilemma. Because the Board is a party to all such appeals and tracks the progress of each case, it is possible to obtain a complete listing of appellate decisions disposing of claims arising under the National Labor Relations Act ("NLRA"). 10 Moreover, decisions reviewing Board adjudications are both numerous and doctrinally coherent, enabling scholars to probe in some depth the differences in publication rates among circuits and judges.

We have compiled a database encompassing all appellate cases decided between October 1986 and November 1993 that resolve unfair labor practice claims under the NLRA. ${ }^{11}$ As we discuss more fully below, a rich array of variables distinguishes published from unpublished opinions in our dataset. Some of these, such as a decision to reverse the agency, track formal publication rules. Others, such as the number of judges on a panel who graduated from elite law schools or the number of panel judges with experience rep-

\footnotetext{
the "reasons for rejecting [the precedent] . . . made convincingly clear." Id. at 905. Within the Eighth Circuit, moreover, only the en banc court may overrule a panel decision. Id. at 904.

10. National Labor Relations Act, 29 U.S.C. $\$ \S 151-169$ (1994).

11. The database derives from one we analyzed in James J. Brudney, Sara Schiavoni, \& Deborah J. Merritt, Judicial Hostility Toward Labor Unions? Applying the Social Background Model to a Celebrated Concern, 60 OHIO ST. L.J. 1675 (1999). That article includes a more exten. sive discussion both of how we built the database and of the variables it contains. As explained further below, we reorganized the database for the current study so that we could analyze by case (the appropriate unit for publication decisions) rather than by individual judges' votes on particular issues.
} 
resenting management clients in NLRA matters, suggest departures from the rules. We also discovered substantial evidence of partisan disagreement among unpublished opinions, suggesting that those cases are not as uncontroversial as publication rules presume them to be. Understanding these diverse effects is crucial for litigants dependent upon appellate precedents, for policymakers concerned about the impact of limited publication rules, and for legal academics and social scientists who rely upon databases of published opinions to track judicial behavior.

In the first part of this Article, we briefly describe the evolution of limited publication plans in the United States Courts of Appeals. In Part II, we describe our database and the variables we constructed. Part III explores the variables distinguishing published from unpublished opinions, as well as indicia of controversy among unpublished decisions. The final section of the Article discusses the implications of these findings for lawyers, policymakers, judges, legal academics, and social scientists. In particular, we note that some of our empirical findings lend support to the Eighth Circuit's conclusion that the Constitution requires Article III courts to accord all of their decisions precedential value.

\section{LIMITED PUBLICATION IN THE COURTS OF APPEALS}

In 1964, the Judicial Conference of the United States resolved that the courts of appeals should publish "only those opinions which are of general precedential value."12 The courts responded to this mandate slowly; until the mid-1970s, courts of appeals continued to publish a substantial majority of their opinions. ${ }^{13}$ In 1972, however, the Conference fortified its mandate by requiring each circuit to develop a publication plan. ${ }^{14}$ By 1974, each of the

12. REPORTS OF THE PROCEEDINGS OF THE JUDICIAL CONFERENCE OF THE UNTED STATES: 1964 ANNUAL REPORT OF THE DIRECTOR OF THE ADMINISTRATIVE OFFICE OF THE UNITED STATES COURTS 11 (1965). The resolution also applied to district courts, but we focus exclusively on the courts of appeals in this Article. For helpful discussions of the evolution of limited publication rules, see Dragich, supra note 6, at 760-64; Reynolds \& Richman, Price of Reform, supra note 6, at 577-79; Songer, supra note 6, at 307-08.

13. See, e.g., Leonard I. Garth, Views from the Federal Bench: Past, Present \& Future, 47 RUTGERS L. REv. 1361, 1364 (1995) (recalling that the Third Circuit published opinions in all cases through the early 1970s); Songer, supra note 6 , at 308 (suggesting that the percentage of unpublished opinions did not begin to escalate sharply in most circuits until the mid-1970s, and was still as low as $33.6 \%$ in the Eighth Circuit in 1984).

14. REPORTS OF THE PROCEEDINGS OF THE JUDICIAL CONFERENCE OF THE UNTTED STATES: 1972 ANNUAL REPORT OF THE DIRECTOR OF THE ADMINISTRATIVE OFFICE OF THE UNITED STATES COURTS 33 (1973). 
circuits had complied with this request and the Conference had approved their plans. ${ }^{15}$ The number of unpublished opinions "escalate[d] sharply" after that time. ${ }^{16}$ By 1978-79, half of federal appellate dispositions were unpublished; 17 the figure reached two-thirds by $1989 .{ }^{18}$ Today, almost $80 \%$ of the courts' merits dispositions are unpublished. ${ }^{19}$

Each circuit maintains formal rules governing the publication of opinions. The rules attempt to limit publication to decisions that "add to the body of law" and "have value as precedent." ${ }^{20} \mathrm{Be}$ -

15. See Reynolds \& Richman, Price of Reform, supra note 6, at 578-79; Songer, supra noto 6, at 308 .

16. Songer, supra note 6 , at 308 . As other scholars have recognized, the phrase "unpublished opinions" is somewhat euphemistic. See, e.g., Reynolds \& Richman, Price of Reform, supra note 6 , at 585 . The category includes orders, judgments, and memoranda, many containing littlo judicial reasoning. It might be more accurate to refer to these cases as "unpublished dispositions." The cases, however, all represent judicial dispositions on the merits after oral argumont and/or submission of formal briefs. See infra note 17. They are "unpublished opinions" in tho sense that they are unpublished dispositions that might have produced published opinions. Wo thus follow the convention of other scholars in referring to these dispositions as "unpublished opinions." See, e.g., Reynolds \& Richman, Price of Reform, supra note 6, at 585 \& n.40.

17. See REPORTS OF THE PROCEEDINGS OF THE JUDICIAL CONFERENCE OF THE UNITED STATES: 1979 ANNUAL REPORT OF THE DIRECTOR OF THE ADMINISTRATIVE OFFICE OF THE UNITED STATES COURTS 344-46 tbl. B-1 (1980) [hereinafter 1979 ANNUAL REPORT] (reporting 9,361 cases disposed of after oral argument or submission on the briefs); Reynolds \& Richman, Price of Re. form, supra note 6 , at $584 \&$ n.39, 586 (reporting that 4,699 out of 12,419 opinions were pub. lished for the year ending June 30,1979 ). The 4,699 published opinions comprised $50.2 \%$ of the 9,361 merits dispositions.

Reynolds and Richman estimated that as many as $61.7 \%$ of all dispositions were unpublishod in 1978-79, Reynolds \& Richman, Price of Reform, supra note 6, at 587, but they included all "appeals terminated 'by judicial action'" in those calculations. Id. at 585 n.45. That larger universe includes cases resolved without formal briefs or oral argument, including "motions for summary affirmance, motions for stays, and motions for bail reductions." Id. at 586 n.45. Ono could dicker over the set of dispositions that might produce published opinions, but we prefer tho Administrative Office of the U.S. Courts' more conservative definition of "cases disposed of aftor hearing or submission," 1979 ANNUAL REPORT, supra, and use that definition to calculate tho percentage of published opinions throughout this Article. In more recent years, the courts havo referred to that category as "cases terminated on the merits after oral hearings or submission on briefs." 1999 ANNUAL REPORT, supra note 1, 49 tbl. S-3. In any event, it bears noting that our estimate of the percentage of unpublished opinions is conservative. If we adopted the somowhat broader universe of cases studied by Reynolds and Richman, the percentage of unpublished opinions would be even higher.

18. See REPORTS OF THE PROCEEDINGS OF THE JUDICIAL CONFERENCE OF THE UNITED STATES: 1989 ANNUAL REPORT OF THE DIRECTOR OF THE ADMINISTRATIVE OFFICE OF THE UNITED STATES COURTS 109 tbl. S-5 (1990) (showing that $64.6 \%$ of merits dispositions were unpublishod).

19. See 1999 ANNUAL REPORT, supra note 1 , at 49 tbl. S-3.

20. 8TH CIR. R. App. I; see also D.C. CIR. R. 36(a) (stating that the court's policy is to publish opinions that have "general public interest"); 5TH CIR. R. 47.5.1 (stating that opinions "that may in any way interest persons other than the parties to a case should be published"). Throughout this section, we cite the circuit rules in effect in 1993, the end of the seven-year period wo studied. Most circuits have not changed those rules substantially since 1993. But see supra notes 8.9 and accompanying text (noting Eighth Circuit's recent decision striking its rule governing lim- 
yond that core objective, the rules display considerable variety in their details. During the time period we studied, six circuits encouraged or required publication of decisions reversing the lower court or agency, while the other six were silent on this issue. ${ }^{21}$ Four circuits favored publication of decisions including a dissent or concurrence, but the other eight omitted any mention of this criterion. ${ }^{22}$ The rules of four circuits suggested that a single judge from the deciding panel could force publication of an opinion; ${ }^{23}$ four

ited citation and precedential effect of unpublished opinions). Eleven of the twelve circuits, moreover, maintained the same publication rules in all relevant respects during the full seven years we studied. For the Tenth Circuit, the only circuit that changed relevant rules between 1986 and 1993, we discuss both versions of the rules. See infra notes 28, 31, and accompanying text.

21. Courts were especially likely to require, rather than encourage, publication if the appellate decision reversed a published opinion. See D.C. CIR. R. 14(b) (1993) ("An opinion, memorandum, or other statement explaining the basis for this Court's action ... . shall be published if ... it reverses a published agency or district court decision."); 5TH CIR. R. 47.5.1 (1993) ("An opinion may also be published if it . . . reverses the decision below."); GTH CLR. R. 24(a) (1993) ("The following criteria shall be considered by panels in determining whether decisions will be designated for publication . . . whether it reverses the decision below."); 7TH CIR. R. 53(c)(1)(v) (1993) ("A published opinion will be filed when the decision . . . reverses a judgment or denies enforcement of an order when the lower court or agency has published an opinion supporting the judgment or order."); 8TH CIR. R. App. II (1993) ("An opinion should be published when the case or opinion ... does not accept the rationale of a previously published opinion in that case."). The Ninth Circuit's rules seem to favor publication of cases reversing published dispositions by implication. The rules provide for opinion status (and thus publication under that court's nomenclature) if the appellate decision disposes "of a case in which there is a published opinion by a lower court or administrative agency, unless the panel determines that publication is unneosssary for clarifying the panel's disposition of the case." 9TH CIR. R. 36-2 (1993). Presumably reversals would require that clarification, because the agency's or lower court's rationale would not support the result.

22. See 1ST CIR. R. 36.2(b)(3) (1993) (When a panel decides a case with a dissent, or with more than one opinion, the opinion or opinions shall be published unless all the participating judges decide against publication."); 2D CIR. R. 0.23 (1993) (authorizing summary disposition with unpublished memoranda only "in those cases in which decision is unanimous"); 5TH CIR. $R$. 47.5.1 (1993) ("An opinion may also be published if it . . . is accompanied by a concurring or dissenting opinion."); 9TH CIR. R. 36-2(1) (1993) ("A written, reasoned disposition shall be designated as an OPINION [and published under Rule 36-1] ... if it . . . [i]s accompanied by a separate concurring or dissenting expression, and the author of such separate expression requests publication of the disposition of the Court and the separate expression.").

23. See 1ST CIR. R. 36.2(b)(2) (1993) ("With respect to cases decided by a unanimous opinion with a single opinion, ... [a]fter an exchange of views, should any judge remain of the view that the opinion should be published, it shall be."); id. 36.2(b)(3) (1993) (any case generating more than one opinion "shall be published unless all the participating judges decide against publica. tion"); 2D CIR. R. 0.23 (1993) (authorizing summary disposition without published opinion only if "each judge of the panel believes that no jurisprudential purpose would be served by a written opinion"); 5 TH CIR. R. 47.5.2 (1993) ("An opinion shall be published unless each member of the panel deciding the case determines that its publication is neither required nor justified under the criteria for publication."). The Eighth Circuit's rule was not quite as firm as these others but appeared to give individual judges the power to force publication as long as they had authored some opinion in the case. 8TH CIR. R. App. II (1993) (The Court or a panel will determine which of its opinions are to be published, except that a judge may make any of his opinions available for 
others explicitly required a majority to publish a disposition; ${ }^{24}$ and the final four did not discuss this issue. ${ }^{25}$ Nine circuits enumerated criteria for making the publication decision beyond the ones already mentioned here, ${ }^{26}$ while two omitted any additional criteria. ${ }^{27}$ The Tenth Circuit enumerated additional criteria during the first part of the period we studied, but dropped those criteria after January 1 , 1989.28

Perhaps the most marked formal difference among the circuits lay in their rules governing citation of unpublished opinions. Throughout the period we studied, six of the circuits prohibited citation of unpublished dispositions except to establish res judicata, law of the case, or similar points. ${ }^{29}$ Four other circuits permitted

publication."). We thus counted the Eighth Circuit among courts giving an individual judge the power to force publication. The Fourth Circuit, in contrast, gave an individual judge the power to force publication only if that judge had authored the primary opinion in the case and the case had been "formally briefed and presented at oral argument." 4TH CIR. R. 36.3 (1993). We viewed this rule as too restrictive to give an individual judge power to force publication in a substantial number of cases.

24. See 3D CIR. I.O.P. ch. V(F)(3) (1993) ("the determination is made by a majority of the panel"); 6TH CIR. R. 24(b) (1993) ("opinions shall be designated for publication unless a majority of the panel deciding the case determines otherwise"); 7TH CIR. R. 53(d)(1) (1993) ("The determination to dispose of an appeal by unpublished order shall be made by a majority of the panol rendering the decision."); 9TH CIR. R. 36-5 (1993) ("An order may be specially designated for publication by a majority of the judges acting.").

25. But see supra note 23 (describing the Fourth Circuit's limited rule with respect to cases formally briefed and presented at oral argument).

26. Typical criteria included those listed by the Seventh Circuit, which required publication of any decision that

(i) establishes a new, or changes an existing rule of law; (ii) involves an issue of continuing public interest; (iii) criticizes or questions existing law; (iv) constitutes a significant and non-duplicative contribution to legal literature (A) by a historical review of law, (B) by describing legislative history, or (C) by resolving or creating a conflict in the law; ... or (vi) is pursuant to an order of remand from the Supreme Court and is not rendered merely in ministerial obedience to specific directions of that Court.

7TH CIR. R. 53(c) (1993).

27. The Second Circuit provided simply for nonpublication in "those cases in which decision is unanimous and each judge of the panel believes that no jurisprudential purpose would bo served by a written opinion." 2D CIR. R. 0.23 (1993). The Eleventh Circuit similarly declared that "[o]pinions that the panel believes to have no precedential value are not published." 11TH CIR. $R$. 36-1 I.O.P. (1993). The rule also exhorted members of the court "to exercise imaginative and innovative resourcefulness in fashioning new methods to increase judicial efficiency and reduco the volume of published opinions." Id.

28. Compare 10TH CIR. R. 17 (as amended Mar. 14, 1979), with 10TH CIR. R. 36 (effectivo Jan. 1, 1989). The Tenth Circuit was the only court that changed its publication rules in any relevant respect during the seven years we studied. See also infra note 31 (describing Tonth Circuit's change in rules governing citation of unpublished opinions).

29. See 1ST CIR. R. 36.1 (1993); 2D CIR. R. 0.23 (1993); 7TH CIR. R. 53(b)(2)(iv) (1993); 8TH CIR. R. App. II (1993); 9TH CIR. R. 36-3; D.C. CIR. R. 11(c) (1993). The Eighth Circuit recontly struck down the successor to its citation rule, holding that Article III of the Constitution requires 
citation of unpublished opinions, although their rules attempted to discourage that practice. ${ }^{30}$ The Tenth Circuit vacillated, allowing citation during the initial years of our study, but prohibiting citation after January 1, 1989. ${ }^{31}$ The Third Circuit had no rule governing citation of unpublished dispositions during the years we studied, but circuit practice regarded these dispositions as lacking precedential value. ${ }^{32}$

Behind these formal rules stands a thicket of circuit practices that may affect publication rates. Many circuits use staff clerks to prepare memoranda disposing of certain cases; those memoranda are less likely to be published than opinions prepared in a judge's chambers. ${ }^{33}$ Staff in many circuits also screen cases for oral argument, exerting substantial influence over which cases ultimately generate published opinions. ${ }^{34}$ All of these practices, as well as the preferences of individual judges, may affect the selection of opinions for publication. Using the database described in the next section, we attempt to discern the factors most likely to predict that outcome.

\section{THE DATABASE}

The courts of appeals adjudicated 1,224 decisions involving unfair labor practice ("ULP") claims under the NLRA between Oc-

all judicial decisions to carry precedential weight. Anastasofi v. United States, 223 F.3d 898 (8th Cir. 2000). The limited citation rule was in effect during the period we studied.

30. See 4TH CIR. R. 36.5 (1993) ("disfavored"); 5TH CIR. R. 47.5.3 (1993) ("should normally be cited" only to establish law of the case or for related purposes); 6TH CIR. R. 24(c) (1993) (disfavored"); 11TH CIR. R. 36-1 I.O.P. (1993) ("looked upon with disfavor").

31. Compare 10TH CIR. R. 17(c) (as amended Mar. 14, 1979) (Unpublished opinions, although unreported, can nevertheless be cited, if relevant, in proceedings before this or any other court."), with 10TH CIR. R. 36.3 (effective Jan. 1, 1989) ("Unpublished opinions and orders and judgments of this court have no precedential value and shall not be cited, or used by any court within the Tenth Circuit, except for purposes of establishing the doctrines of the law of the case, res judicata, or collateral estoppel."). In November 1993, the Tenth Circuit changed once again, suspending its no-citation rule as of January 1, 1994, and allowing citation of unpublished dispositions for their "persuasive value." Tenth Circuit General Order (Nov. 29, 1993). That change, however, occurred after the period we studied.

32. See Reynolds \& Richman, Non-Precedential Precedent, supra note 6, at 1180-81. The court later incorporated a formal reference in its internal operating procedures, noting that. "[b]ecause the court historically has not regarded unpublished opinions as precedents that bind the court, the court by tradition does not cite to its unpublished opinions as authority." 3D CLR. I.O.P. 5.8. The reference, however, still stopped short of prohibiting citations by counsel.

33. See Stephen Breyer, The Donahue Lecture Series: Administering Justice in the First Circuit, 24 SUFFoLK U. L. REV. 29, 33, 43 (1990); Reynolds \& Richman, Price of Reform, supra nate 6 , at 624-25.

34. See William M. Richman \& William L. Reynolds, Elitism, Expediency, and the New Certiorari: Requiem for the Learned Hand Tradition, 81 CORNELL L. REV. 273, $290-92$ (1996). 
tober 28, 1986 and November 2, 1993. Those cases include three major categories of claims: allegations that an employer engaged in an unfair labor practice under section 8(a); charges that a union committed an unfair labor practice under section 8(b); and disputes under section 10(c) regarding the nature and scope of relief against employers found liable for section 8 (a) violations. ${ }^{35}$

We obtained a complete list of these appellate decisions from the Appellate Division in the National Labor Relations Board's Office of General Counsel. About one quarter of the appellate decisions (22.9\%) reversed, remanded, or modified a Board order; we coded all 280 of these "reversals" for our database. Of the remaining 944 cases that wholly enforced or affirmed a Board order, we analyzed a stratified random. sample of 275 decisions. ${ }^{36}$ We then weighted these sampled affirmances to reflect their presence in the full population. Our access to the full population of appellate decisions in this field of law is unusual, affording a special opportunity to analyze publication decisions.

After analysis, we excluded 25 of the reversals because they involved exclusively procedural, jurisdictional, or constitutional issues that differed substantially from the core ULP issues raised in the other appeals. ${ }^{37}$ We likewise excluded 17 of the sampled affirmances (representing 59 affirmances from the full population) because they focused exclusively on these same distinctive issues. Cases that discussed these threshold issues in combination with ULP claims, however, remained in the database. ${ }^{38}$ Our final data-

35. For further discussion of these categories, see infra notes 47-54 and accompanying toxt. n.71.

36. Cases were stratified by year. See Brudney, Schiavoni, \& Merritt, supra note 11, at 1695

37. Procedural matters included issues such as timeliness or waiver of a claim, as well as a distinct category of arguments questioning the status of an employer as a successor in the con. text of a sale, acquisition, or merger. Jurisdictional claims challenged the Board's authority ovor certain categories of workers or its compliance with interstate commerce requirements. Most constitutional claims raised procedural due process issues.

38. Overall, the number of threshold issues remaining in the database was vory small. Twenty-four unweighted cases, representing a total of 67.71 decided cases, raised successor claims; thirty-two unweighted cases, representing 97.61 decided cases, considered other proco. dural claims; seventeen unweighted cases, representing 48.20 decided cases, resolved jurisdictional issues; and two unweighted cases, representing 6.90 cases, included constitutional claims. As explained further below, we controlled for the presence of the first three of theso threshold issues when analyzing publication rates for ULP claims. See infra notes 50-51 and accompanying text.

In addition to the procedural, jurisdictional, and constitutional issues noted above, we ex. cluded a handful of cases involving two groups of unusual ULP issues: cases questioning "the scope and content of relief against a union" (rather than against the employer) and cases in "which employees prevailed against both an employer and a union." Brudney, Schiavoni, \& Morritt, supra note 11, at 1696 n.77. These cases were few in number and differed materially from 
base included 255 reversals and 258 weighted affirmances, representing a total of 1,140 decisions reviewing ULP claims during a seven-year period. ${ }^{39}$

The dependent variable for most of the analyses in this Article denotes whether the case yielded a published opinion in the Federal Reporter. We coded opinions excluded from the Federal Reporter as "unpublished," even if their text appeared in an electronic database or specialized reporter. ${ }^{40}$ The current analyses thus focus on differences between cases the circuits designate for formal publication and all other cases. Although our study concentrates on ULP decisions, there is little reason to believe that courts use dramatically different criteria to make publication decisions in other areas of law. Publication rates and criteria may vary somewhat among legal fields, but published ULP cases possess no features that would make them outliers compared to other cases.

For each case, we also coded more than two dozen independent variables. Six of those variables describe basic features of the case: the circuit deciding the appeal; the number of issues resolved; presence of a dissent; presence of a concurrence; whether the court reversed the Board on any issue; ${ }^{41}$ and whether the court's decision favored the union. 42

the ULP cases we analyze here. In contrast to the procedural, jurisdictional, and constitutional issues, none of the cases retained in our database included these unusual ULP claims as adjunct issues.

39. Although we round off the number of decisions in text, decision totals are not round numbers because of the manner in which we weighted sampled afirmances. The 258 sampled affirmances actually represent 884.76 affirmed decisions for a total of 1,139.76 "decisions" in the database.

40. The circuits vary widely in the extent to which they malse unpublished opinions available electronically. See Ruth Colker, The Americans with Disabilities Act: $A$ Windfall for Defendants, 34 HARV. C.R.-C.L. L. REV. 99, 104-05 (1999). Three circuits withhold their unpublished opinions from all electronic databases; the others distribute unpublished opinions through Westlaw, Lexis, Public Access to Court Electronic Records ("PACER"), or their own websites. Id. at 104 n.30. Lexis and Westlaw download opinions from the latter two sources. Whether they receive unpublished opinions directly from the courts or from these other sources, Lexis and Westlaw include only some unpublished dispositions in their databases. Sce id.

41. Because we hypothesized that any reversal might favor publication, we coded a case as "reversed" as long as the court reversed, remanded, or vacated a Board judgment on any issue. Cases in which some issues were affirmed and others reversed, therefore, appear in our database as reversals.

42. We coded a case as favoring the union only if the court disposed of all issues in the union's favor. A substantial majority of appellate cases resolving ULP claims (69.1936) entirely favor the union. See also Brudney, Schiavoni, \& Merritt, supra note 11, at 1714 tbl. I (reporting that $76 \%$ of all judicial votes on distinct issues in ULP cases favor the union). We therefore hypothesized that any departure from the pro-union norm, even involving a single issue, might favor publication.

Pro-union outcomes in the courts of appeals largely reflect the nature of cases appealed to those courts from the National Labor Relations Board. During the period we studied, $88 \%$ of the 
Seven other variables reflect characteristics of the circuit in which the case was decided. One of these circuit variables designates the total number of ULP cases resolved by the circuit during the years we studied. A second indicates whether the circuit allowed citation of unpublished opinions during the period we analyzed. ${ }^{43} \mathrm{~A}$ third variable marks circuits that encouraged publication of reversals, while a fourth distinguishes circuits that favored publication of opinions including a concurrence or dissent.44 The fifth variable denotes circuits that allowed a single judge on the panel to force publication of an opinion, and a sixth designates circuits that explicitly required a majority of the panel to agree to publication. ${ }^{45}$ A final circuit variable indicates whether the circuit rules announced specific criteria for publication other than references to reversals or split opinions. ${ }^{46}$

Six other variables identify cases in which distinctive types of issues were resolved on appeal. One variable notes the presence of a claim arising under section 8(a)(5) of the Act; those claims allege an employer's failure to bargain in good faith with a recognized union. ${ }^{47}$ Another distinguishes claims arising under section 8(b) of the Act; those claims target ULPs by unions rather than

issues appealed to the courts had been resolved in favor of the union by the Board. Brudnoy, Schiavoni, \& Merritt, supra note 11, at 1714 tbl. I. That figure, of course, does not reflect the full universe of cases brought under the NLRA: over $90 \%$ of such disputes are dismissed, withdrawn, or settled before a case is tried or appealed to the Board. See William N. Cooke et al., The De. terminants of NLRB Decision-Making Revisited, 48 INDUS. \& LAB. REL. REV. 237, 238-39 (1995) (stating that the Board decided only about $2.5 \%$ of all ULP cases closed in fiscal year 1990); 55 NLRB ANN. REP. 157 (1990) (showing that, out of more than 32,000 unfair labor practice cases closed in fiscal year 1990, fewer than 1,100 reached stage of a Board order); 54 NLRA ANN. REP. 211 (1989) (showing that, in fiscal year 1989, fewer than 1,100 of nearly 30,000 closed cases reached the stage of a Board order).

43. See supra notes 29-32 and accompanying text (discussing variation in citation practices). We counted the Third Circuit among the courts allowing citation, because it never prohibited that practice. See supra note 32. The Tenth Circuit changed its citation rule during the years wo studied; we coded Tenth Circuit cases according to the prevailing rule at the time they wore decided.

44. See supra notes 21-22 (describing circuit variation on these publication criteria).

45. As noted above, four circuits did not address the number of judges needed to publish an opinion. See supra note 25 and accompanying text. Those four circuits formed the reference category for the two dummy variables described above.

46. See supra notes $26-28$ and accompanying text.

47. 29 U.S.C. $\S 158(a)(5)$ (1994). These claims include some "technical" violations of section $8(a)(5)$ in which the employer sought to challenge the Board's certification of the union based on either the scope of the bargaining unit or alleged union misconduct during the election campaign. Because the Board's certification of election results under section 9(c) is not a final order, em. ployers who wish to test the validity of a certification typically do so by refusing to bargain with the union. This produces a violation of section $8(a)(5)$ that is appealable to the courts. 
employers. ${ }^{48} A$ third variable denotes remedial issues raised under section 10(c) of the Act. ${ }^{49}$ Three other variables designate threshold issues resolved in conjunction with ULP claims. ${ }^{50}$ One of these represents arguments over whether an employer qualified as a "successor" to another employer under the Act; a second designates procedural issues such as waiver or the timeliness of claims; and the third marks challenges to the Board's substantive jurisdiction, including claims that the Board failed to demonstrate a sufficient connection with interstate commerce or that it attempted to exert authority over exempt categories of employees. 51

These six "issue" variables were not mutually exclusive; a case raising both a threshold procedural issue and a section $8(a)(5)$ claim received positive codes for both of these variables. We defined all of these categories in contrast to the most common category of issues in ULP cases: claims arising under sections $8(a)(1)$ or $8(a)(3)$ of the Act.52 Those sections focus primarily on employees' right to organize in order to achieve union representation; they constitute almost half (44.87\%) of issues adjudicated by the courts of appeals in ULP cases.53 The reference category for all six of our issue variables, in other words, is cases adjudicating only section $8(a)(1)$ or 8(a)(3) claims. ${ }^{54}$

In addition to variables describing basic features of each case, the circuit in which it arose and the issues adjudicated, we

48. Id. §I58(b). A de minimis number of claims against unions were filed under section $8(e)$ of the Act. See id. $\S 158(\mathrm{e})$. We combined the latter claims with the analogous, and much more numerous, section 8(b) claims for the analyses in this Article.

49. Id. § 160 (c) (authorizing the Board to issue cease and desist orders, as well as orders to take affirmative action including reinstatement of employees and back pay awards).

50. As noted above, we excluded cases in which the only issues decided by the courts of appeals were threshold ones. See supra notes $37-38$ and accompanying text.

51. We considered one other threshold issue, constitutional claims. Only two cases in our database, however, included these claims, so we did not create a variable distinguishing such claims.

52. 29 U.S.C. $\S \S 158(a)(1),(3)$ (1994). Section $8(a)(1)$ claims allege employer interference with employee attempts to secure union representation, generally through threats, interrogations, or improper conferral of benefits. Section $8(a)(3)$ claims allege employer discrimination against union members or supporters, typically arising out of terminations, layofis, or failures to recall or rehire. In a small number of cases, unions or employees charged employer misconduct under section $8(\mathrm{f})$. Id. $\S 158(\mathrm{f})$. We grouped those claims with analogous section 8(a) claims for the analyses in this Article.

53. See Brudney, Schiavoni, \& Merritt, supra note 11, at 1707, 1714 tbl. I.

54. A small number of cases included claims arising under subsections of $8(a)$ other than the ones described in text. These included claims of employer domination of labor organizations arising under section $8(a)(2)$ and alleged retaliation for filing a charge with the NLRB, brought under section 8(a)(4). In preliminary analyses, we distinguished these claims from other section 8(a) claims, but found no significant effects. The analyses reported here group these miscellaneous section 8(a) claims with the section 8(a)(1) and (3) claims. 
created nine variables describing characteristics of the judges deciding each case. Five of these variables indicate the number of judges on each panel who (1) were appointed by a Democratic President; 55 (2) were female; (3) graduated from an elite law school:56 (4) had experience representing management clients in NLRA cases; ${ }^{57}$ and (5) had exclusively union, government, or academic (non-management) experience under the NLRA. ${ }^{58}$ We coded each of these variables $0,1,2$, or 3 for each case, representing the number of judges holding that characteristic on the panel. Three other variables indicate whether any judges on the panel were (6) members of a minority race; (7) district court judges sitting by designation; or (8) court of appeals judges sitting by designation from another circuit. ${ }^{59}$ A final "judicial characteristic" variable reflects (9) the average age of the three judges deciding each case. ${ }^{60}$

As explained further below, we modified some of these judicial characteristic variables to test specific hypotheses. Our basic analyses, however, follow the coding scheme outlined above.

55. As in other studies of judicial attitudes, we relied upon the party of the appointing President as a proxy for the judge's own political inclinations. See Brudney, Schiavoni, \& Merritt, supra note 11, at 1689-92, 1702.

56. We used the 1977 Cartter Report to choose fifteen schools for this elite group. See The Cartter Report on the Leading Schools of Education, Law, and Business, CHANGE, Feb. 1977, at 44, 46; Brudney, Schiavoni, \& Merritt, supra note 11, at 1704 n.105. The fifteen schools are Borkeley, Chicago, Columbia, Cornell, Duke, Harvard, Michigan, NYU, Northwestern, Pennsylva. nia, Stanford, Texas, UCLA, Virginia, and Yale. Id.

57. Judges in this category included both those whose exclusive NLRA experience was on behalf of management and those whose experience included union, government, or academic work as well as management representation.

58. We excluded from this category judges who combined union, government, or academic experience involving the NLRA with management experience under that statute. Judges with such mixed experience were grouped with purely management attorneys in our previous variable. An alternate set of analyses, coding judges with mixed experience positive for both NLRA variables, did not differ materially from the analyses reported below; the variable for NLRA management experience was significant, while that for other types of NLRA experience was not.

59. We coded these variables as dichotomies, rather than as ordinal variables stretching from zero to three, because very few panels included more than one judge falling into any of these categories. Eight panels included two minority judges; two included two district court judges; none included more than one appellate judge visiting from another circuit. We did not distinguish between active and senior judges serving within their own circuit.

60. We measured age at the time of decision. See Brudney, Schiavoni, \& Merritt, supra noto 11 , at 1702 \& n.98. We tested numerous other judicial characteristics in our exploration of pub. lication rates, but none had significant explanatory power. Tested attributes include religion; status of college attended; workplace law experience falling outside the NLRA; experience representing business clients with no exposure to workplace law; pre-judicial service as a full-time academic; service on a different court before appointment to the court of appeals; pre-judicial elected office experience; pre-judicial experience in a nonelective government position; and year of appointment to the court of appeals. See id. at 1702-05 (discussing these tested variables). 


\section{RESULTS}

In this section, we explore six types of analyses. First, we look simply at intercircuit variation in citation rates, as well as some formal characteristics distinguishing the circuits from one another. Second, we add half a dozen case characteristics (such as the presence of a dissent or concurrence) to our analyses. Next, we introduce variables representing judicial characteristics (such as gender or political background) on each of the deciding panels. Fourth, we look specifically for any evidence that judges engage in strategic behavior to publish outcomes with which they agree or to suppress results that cause them discomfort. Fifth, we consider whether homogeneous panels-those that share a common gender, political party, or other trait-are more or less likely to publish opinions than heterogeneous panels. Finally, we examine whether unpublished opinions should be viewed as merely routine applications of the law or whether there is evidence linking those opinions to certain indicia of controversy.

\section{A. Intercircuit Variation}

The circuits vary markedly in the percentage of unfair labor practice opinions they publish. As Table I shows, the Third Circuit published just one-quarter of its ULP decisions, while the Seventh Circuit published nine-tenths of those opinions. These percentages, like several others, depart dramatically from the nationwide average of $53.36 \%$ published opinions in ULP cases. 
Table I: Publication Rates by Circuit

\begin{tabular}{|l|l|l|l|l|}
\hline Circuit & $\begin{array}{l}\text { Number of } \\
\text { ULP Opinions } \\
\text { Published }\end{array}$ & $\begin{array}{l}\text { Total Number } \\
\text { ULP Opinions }\end{array}$ & $\begin{array}{l}\text { Percentage of } \\
\text { ULP Opinions } \\
\text { Published }\end{array}$ & $\begin{array}{l}\text { Percontage of } \\
\text { all Opinions } \\
\text { Publishod }\end{array}$ \\
\hline \hline D.C. & 81.05 & 129.38 & $62.64 \%$ & $38.58 \%$ \\
1st & 12.94 & 19.79 & $65.39 \%$ & $62.35 \%$ \\
2d & 46.05 & 104.41 & $44.10 \%$ & $36.63 \%$ \\
3d & 27.58 & 114.33 & $24.12 \%$ & $19.28 \%$ \\
4th & 28.69 & 70.59 & $40.64 \%$ & $16.53 \%$ \\
5th & 24.94 & 51.86 & $48.09 \%$ & $27.88 \%$ \\
6th & 90.14 & 187.40 & $48.10 \%$ & $20.46 \%$ \\
7th & 118.67 & 129.98 & $91.30 \%$ & $51.35 \%$ \\
8th & 51.25 & 62.50 & $82.00 \%$ & $43.53 \%$ \\
9th & 80.68 & 182.08 & $44.31 \%$ & $23.08 \%$ \\
10th & 18.23 & 38.81 & $46.97 \%$ & $34.48 \%$ \\
11th & 27.97 & 48.63 & $57.52 \%$ & $25.85 \%$ \\
\hline Nationwide & 50.68 & 94.98 & $53.36 \%$ & $33.25 \%$ \\
Mean & & & & \\
\hline \hline
\end{tabular}

Numbers of opinions are not whole numbers because of weighting.

In every circuit, the percentage of published ULP opinions exceeded the overall percentage of published opinions. ${ }^{61}$ Overall publication rates probably lag behind ULP rates because the former category includes prisoner appeals, social security claims, and other routine dispositions that the courts frequently decide without published opinion. It is noteworthy, however, that ULP publication rates correlate highly with overall publication rates $(r=.744$, $p=.006$ ). Circuits that published a higher percentage of ULP opin-

61. The final column of Table I shows the percentage of all opinions published by each circuit between July 1, 1989, and September 30,1993. We calculated these percentages by averag. ing the annual figures reported in Table S-3 of the 1990, 1991, 1992, and 1993 annual reports of the Director of the Administrative Office of the United States Courts. See REPORTS OF THE PROCEEDINGS OF THE JUdicial CONFERENCE OF THE UNITEd STATES: 1993 ANNUAL REPORT OF THE DIRECTOR OF THE ADMINISTRATIVE OFFICE OF THE UNITED STATES COURTS tbl. S.3 (1994); REPORTS OF THE PROCEEDINGS OF THE JUDICIAL CONFERENCE OF THE UNITED STATES: 1992 ANNUAL REPORT OF THE DIRECTOR OF THE ADMINISTRATIVE OFFICE OF THE UNITED STATES COURTS tbl. S-3 (1993); REPORTS OF THE PROCEEDINGS OF THE JUDICIAL CONFERENCE OF THE UNITED STATES: 1991 ANNUAL REPORT OF THE DIRECTOR OF THE ADMINISTRATIVE OFFICE OF THE

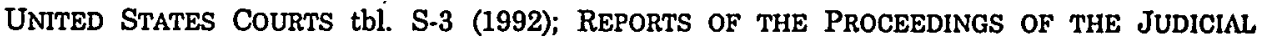
CONFERENCE OF THE UNITED STATES: 1990 ANNUAL REPORT OF THE DiRECTOR OF THE ADMINISTRATIVE OFFICE OF THE UNITED STATES COURTS tbl. S-3 (1991). Before 1990, the courts did not calculate percentages of published and unpublished opinions. Scholarly studies, howover, suggest that the percentage of published ULP opinions exceeded the overall percentage of published opinions before 1990 as well. Songer, for example, found that the Fourth, Eloventh, and D.C. Circuits decided just $28.2 \%$ of their cases by published opinion in 1986, the year before our study began. Songer, supra note 6 , at 311 . Table I, in contrast, shows that those circuits decided $40.64 \%, 57.52 \%$, and $62.24 \%$ of their ULP appeals with published opinions. 
ions, in other words, also tended to publish a higher percentage of decisions overall. This correlation suggests that publication decisions in ULP cases provide reasonable insight into those decisions in other types of cases.

Our first set of analyses considers whether differences in formal publication rules or ULP caseload account for any of the variation in ULP publication rates among circuits. For example, courts deciding a large volume of ULP cases might publish a lower fraction of those cases because judges with greater experience adjudicating such controversies may perceive the marginal value of additional precedents as small. ${ }^{62}$ Conversely, circuits encouraging publication of reversals might publish a higher percentage of their decisions than circuits whose rules do not expressly encourage publication of those dispositions.

Table II reports publication rates for each of the variations in circuit caseload or rules that we studied. ${ }^{63}$ The table suggests that circuits deciding a low volume of ULP cases published a somewhat higher fraction of their decisions than did circuits resolving a high volume of those cases, but the difference was not statistically significant in this bivariate analysis. ${ }^{64}$ Circuits that encouraged

62. See Horton, supra note 5, at 1696 . This phenomenon might be especially likely to occur under a mature statute like the NLRA; appellate cases may be less likely to break new ground after several generations of precedent from the Supreme Court.

63. For purposes of this table only, we divided circuits into "high volume" circuits (those that decided more than one hundred ULP cases during the seven years ve studied) and "low volume" circuits (those deciding fewer than one hundred ULP cases during the same period). As can be seen from Table I, supra, virtually every circuit is either substantially below the one hundred mark or substantially above that level. Only the Second Circuit, which decided 104 cases, is close to our chosen demarcation point. In the multivariate analyses reported below, we use the actual number of ULP cases decided by each circuit, rather than this dichotomous variable.

64. We follow the common social science convention of designating results with a p-value of .05 or less as "significant." See Davi S. MOORE, STATISTICS: CONCEPTS AND CONTROVERSIES 416 (3d ed. 1991). See generally HubERT M. BlaLOCK, Social Statistics (2d rev. ed. 1979). For convenience, we separately note results with a p-value of .01 or less. A result that is significant at the .05 level has no more than a $5 \%$ probability of occurring through random error in sampling or coding, while one that is significant at the .01 level has no more than a $1 \%$ probability of occurring through those random processes.

Throughout this Article, we also designate results with a p-value of .10 or less as "approaching significance." Those results have no more than a one-in-ten chance of stemming from random errors. Social scientists sometimes treat such results as identifying relationships that are suggestive or at least warrant further exploration. See MOORE, supra, at 414-20; R. MARK SIRKIN, STATISTICS FOR THE SOCIAL SCIENCES 195-96 (1995). This is particularly true if the results form a consistent pattern with other results that approach or achieve significance. Based on findings in previous studies, we could have reported some of these results as "significant" (i.e, reaching the conventional .05 level) under one-tailed tests of significance. We adopted the conservative approach, however, of treating none of our hypotheses as directional.

The statistical tests in Table II compare the subcategories within each category (e.g., "highvolume circuit" and "low-volume circuit" for volume of ULP cases) using the Rao and Scott sec- 
publication of reversals, on the other hand, published significantly more of their decisions than did other circuits. Somewhat surprisingly, circuits that encouraged publication of opinions carrying dissents or concurrences published a significantly lower percentage of their opinions than did other circuits; we discuss possible reasong for this effect below.

Table II: Publication Rates by Circuit Characteristics

\begin{tabular}{ll}
\hline Circuit Characteristic & Percentage of ULP Opinions \\
\hline \hline High-Volume Circuit & $52.40 \%$ \\
Low-Volume Circuit & $56.14 \%$ \\
\hline Publishing Reversals Encouraged & $60.11 \%{ }^{\star \star \star}$ \\
No Reversal Rule & $40.72 \% \star \star \star$ \\
\hline Publishing Split Ops Encouraged & $45.96 \% \star \star$ \\
No Split Op Rule & $56.75 \% \star \star$ \\
\hline One Judge Causes Publication & $56.66 \%$ \\
Majority Needed to Publish & $51.66 \%$ \\
No Rule & $54.26 \%$ \\
\hline Additional Criteria & $54.20 \%$ \\
No Additional Criteria & $48.93 \%$ \\
\hline Citation of Unpublished Opinions Allowed & $41.96 \% \star \star \star$ \\
No Citation Allowed & $61.75 \% * \star \star$ \\
\hline All Cases & $53.36 \%$ \\
\hline \hline
\end{tabular}

${ }^{\star *} \mathrm{p} \leq .05,{ }^{\star * *} \mathrm{p} \leq .01$

Circuits allowing one judge to mandate publication published a higher fraction of their dispositions than did circuits that failed to specify the number of panel members needed to achieve publication; conversely, circuits requiring a majority consensus for publication published a smaller percentage of their opinions. Neither of these differences, however, was statistically significant. Nor did the publication rate in circuits specifying additional publication criteria differ significantly from that in circuits that failed to specify any criteria. Finally, circuits that prohibited citation of their unpublished opinions published a significantly higher percentage of their opinions than did circuits permitting citation.

When we combined these circuit variables into a regression equation, which allowed us to control simultaneously for variations in case volume and circuit rules, we uncovered several surprises

ond-order correction for weighted data. See 4 STATA REFERENCE MANUAL RELEASE 6, at 82-83 (1999). 
(Table III). ${ }^{65}$ Rules encouraging publication of reversals still showed a significant positive association with publication, while rules favoring publication of split decisions continued to show a significant negative association with that event. Rules allowing citation of unpublished opinions likewise showed a significant negative association with publication. Controlling for these and other factors, however, allowed two other significant relationships to emerge. A case decided in a circuit resolving a large number of ULP claims was significantly less likely to be published than one decided in a circuit with fewer ULP cases. Cases resolved in circuits requiring a majority consensus for publication, on the other hand, were significantly more likely to be published than cases decided in circuits neglecting to specify the number of judges needed for publication. ${ }^{6 s}$

Table III: Logistic Regression for Publication: Circuit Rules and ULP Caseload $(\mathrm{N}=1139.76)$

\begin{tabular}{lcccc}
\hline Variable & Coefficient & Robust Std Error & Sicnificance \\
\hline \hline Total ULP Opinions & $-.0124^{\star \star \star}$ & .0045 & .005 \\
Reversal Rule & $1.4411^{\star \star \star}$ & .3823 & .000 \\
Split Opinion Rule & $-1.0117^{\star \star \star}$ & .3412 & .003 \\
One Judge for Publication & .4038 & .4739 & .394 \\
Majority for Publication & $.8150^{\star \star}$ & .3967 & .040 \\
Additional Criteria & -.6855 & .4640 & .140 \\
Citation Allowed & $-.9181^{\star \star \star}$ & .2658 & .001 \\
Constant & $1.5483^{\star \star}$ & .5769 & .007 \\
\hline Pseudo R & $.0918^{2}$ & & .000 \\
\hline \hline
\end{tabular}

${ }^{\star \star} \mathrm{p} \leq .05,{ }^{\star \star \star} \mathrm{p} \leq .01$

These significant associations do not necessarily imply causation. Formal rules encouraging publication of reversals, for example, may not cause circuits to publish a higher percentage of their opinions. Instead, circuits with a culture favoring publication may be more likely to adopt rules encouraging the publication of

65. Regression analysis is increasingly common in legal scholarship. The technique allows scholars to examine the relationship between an independent variable (such as the number of ULP cases decided by a circuit) and an outcome (the likelihood that an opinion will be published), while controlling for all other variables in the equation. All of our regression analyses employ logistic regression because our dependent variable (publication) is dichotomous. For further discussion of regression equations, see JOHN H. ALDRICH \& FORREST D. NELSON, LINEAR PROBABILITY, LOGIT, AND PROBIT MODELS 9-35 (1984); JANET BUTTOLPH JOHNSON \& RICHARD A. JOSLYN, POLITICAL SCIENCE RESEARCH METHODS 389-401 (3d ed. 1995); SIRKIN, supra note 64, at 446-67 (1995). We used Stata Release 6.0 for all regression analyses in this Article. See 2 STATA REFERENCE MANUAL RELEASE 6, at 200-39 (1999).

66. Notably, the coefficient for circuits allowing a single judge to designate an opinion for publication was also positive, though not significant. The direction of these two coefficients, however, suggests that specifying the number of judges needed to authorize publication-as opposed to the particular number chosen-may be associated with higher publication rates. 
reversals. The negative relationship between publication and rules governing split decisions seems particularly unlikely to be causal. Why would a rule designed to encourage publication of split decisions discourage publication overall? Instead, circuits adopting this rule may have a predisposition against publication, choosing this rule precisely because it favors publication of relatively few decisions. ${ }^{67}$

Overall, differences in caseload and formal rules explained $9.18 \%$ of the variance in publication decisions, suggesting that these factors either play some role in determining publication or correlate with more informal practices playing that role. To explore the role of the latter factors, we created an alternate regression equation using dummy variables for eleven of the twelve circuits instead of the circuit-related variables used in Table III.68 That equation, reported in Table IV, allows us to capture variation among the circuits, whether differences stem from formal rules, bureaucratic structures, or informal practices. ${ }^{69}$

Table IV: Logistic Regression for Publication: Circuits (N=1139.76)

\begin{tabular}{|c|c|c|c|}
\hline Variable & Coefficient & Robust Std. Error & II Significance \\
\hline D.C. Circuit & .5930 & .3922 & .130 \\
\hline 1st Circuit & .7121 & .8591 & .407 \\
\hline 2d Circuit & -.1609 & .4067 & .692 \\
\hline 3d Circuit & $-1.0699 \star \star \star$ & .4456 & .016 \\
\hline 4th Circuit & $\cdot .3027$ & .4463 & .498 \\
\hline 5th Circuit & -.0004 & .4919 & .999 \\
\hline 7th Circuit & $2.4267 \star \star \star$ & .6057 & .000 \\
\hline 8th Circuit & $1.5924 * \star$ & .6273 & .011 \\
\hline 9th Circuit & -.1526 & .3578 & .670 \\
\hline 10th Circuit & -.0452 & .5944 & .939 \\
\hline 11th Circuit & .3790 & .5782 & .512 \\
\hline Constant & -.0760 & .2388 & .750 \\
\hline Pseudo $R^{2}$ & $.1119 * \pi *$ & & .000 \\
\hline
\end{tabular}

67. Only $7.92 \%$ of the cases in our database included a concurrence or dissent. Similarly, in their database of 1978-79 appeals, Reynolds and Richman found that only $12.4 \%$ of published opinions, and $\mathbf{0 . 5 \%}$ of unpublished ones, included separate opinions. Reynolds \& Richman, Price of Reform, supra note 6, at 614. Encouraging publication of nonunanimous cases, therefore, affects a fairly low percentage of decisions.

68. In this substitute equation, we used the Sixth Circuit as the reference category for each of the other circuits. That circuit both decided the largest number of ULP cases and had a publication rate near the national mean.

69. Unfortunately, due to collinearity, we could not include the variables from Table III and the circuit dummies in the same equation. 
The substitute equation in Table IV explains modestly more of the variance in publication, suggesting that circuit-specific factors beyond those specified in Table III play some role in publication rates. The table also confirms that the Third Circuit published significantly fewer of its ULP opinions than the Sixth Circuit did, while the Seventh and Eighth Circuits were significantly more likely to publish their opinions. ${ }^{70}$ For our remaining analyses, we use the circuit-specific variables in Table IV, rather than the ones in Table III, because they better capture both formal and informal differences among the circuits.

\section{B. Case Characteristics and Issues}

Formal publication rules suggest that characteristics of individual cases, such as the presence of a dissent, may help explain differences in publication rates. The doctrinal issues resolved in an opinion may also affect publication; some areas of law may generate decisions with precedential value more readily than other areas. Table V summarizes publication rates for decisions that resolved particular ULP issues or included certain distinguishing features. The table shows that courts were significantly more likely to publish cases resolving section $8(b)$ claims than cases adjudicating section $8(a)(1)$ or (3) issues. ${ }^{71}$ Courts were also significantly less likely to publish an opinion discussing a successor issue, one of the three threshold issues we identified.72 On the other hand, courts were significantly more likely to publish opinions with concurrences or

70. The Third Circuit is notorious for overall low publication rates. See Songer, supra note 6, at 308 (reporting that in 1984, the Third Circuit published only 20.8\% of its dispositions); Gulati \& McCauliff, supra note 4, 184-86 (discussing prevalence of judgment orders in Third Circuit).

71. The courts also appeared more likely to publish cases resolving section 8(a)(5) claims, but this relationship merely approached significance. For explanation of these statutory sections, see supra notes 47-54 and accompanying text. For further discussion of the concept of signif. cance, see supra note 64 . The significance tests reflected in Table V compare the subeategories within each category. For the first two categories (statutory issues and threshold issues), the subcategories were not mutually exclusive, so we used regression analysis (omitting one of the subcategories as a reference) to test for significance. See supra note 65 for further explanation of that technique. Subcategories in the remaining categories were mutually exclusive; we compared those categories using the statistical test described in note 64 supra.

72. Although this difference is notable, caution must be exercised in interpreting it-as well as any other findings related to the threshold issues. We excluded from the database cases resting exclusively on such issues; we analyze here only the relationship of these threshold issues to publication of cases that also resolved substantive or remedial ULP claims. To probe publication rates for jurisdictional or procedural issues fully, one would have to examine a representative sample of all cases adjudicating those claims. We include these variables in our analyses as controls for our investigation of ULP claims. 
dissents rather than those that were unanimous; to publish reversals rather than affirmances; and to publish decisions rejecting union claims rather than those favoring the union. We detected no significant difference between cases resolving multiple issues and those including a single issue. Nor did we find a significant association between the year of decision and the likelihood of publication $(p=.4867) .{ }^{73}$

Table V: Publication Rates by Case Characteristics and Issues

\begin{tabular}{|c|c|}
\hline Case Characteristic & Percentage of ULP Opinions Published \\
\hline $8(a)(1)$ and (3) Issues & $48.41 \%$ \\
\hline $8(a)(5)$ Issue & $56.40 \%$ * \\
\hline 8(b) Issue & $66.27 \%$ ** \\
\hline 10(c) Issue & $53.52 \%$ \\
\hline No Threshold Issues & $53.88 \%$ \\
\hline Successor Issue & $32.70 \% \star \star \star ~$ \\
\hline Jurisdictional Issue & $58.11 \%$ \\
\hline Procedural Issue & $63.68 \%$ \\
\hline Unanimous & 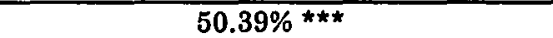 \\
\hline Concurrence & $94.08 \% * \star \star$ \\
\hline Dissent & $86.56 \% \star \star \star *$ \\
\hline All Issues Affirmed & $44.28 \% \star \star \star$ \\
\hline At Least One Issue Reversed & $85.04 \% * * \star$ \\
\hline One-Issue Case & $50.56 \%$ \\
\hline Multiple Issues & $\mathbf{5 5 . 8 1 \%}$ \\
\hline Appellate Outcome for Union & $44.00 \% \star \star \star$ \\
\hline Appellate Outcome against Union & $74.38 \%$ *** \\
\hline All Cases & $53.36 \%$ \\
\hline
\end{tabular}

We added variables reflecting these case characteristics to the regression equation reported in Table IV. The results of that enhanced equation appear in Table VI. The explanatory power of this equation is more than double that of the equation in Table IV, suggesting that case characteristics play an important role in determining publication. ${ }^{74}$ The equation confirms that opinions reversing the Board's decision, as well as those generating a dissent, are significantly more likely to be published than unanimous affirmances, even after controlling for other factors. The coefficient for

73. This result does not fit comfortably in Table V. Publication rates for each year woro: $1986,59.47 \%$; 1987, 57.67\%; 1988, 46.43\%; 1989, 50.63\%; 1990, 61.52\%; 1991, 59.34\%; 1992 , $51.93 \% ; 1993,43.60 \%$. Although these percentages fluctuated around the overall publication rato of $53.36 \%$, the pattern was not significant.

74. When we limited the regression equation to the case characteristics added in Table VI, without including the circuit dummies, the equation explained $15.71 \%$ of the variance in publication decisions-more than all of the circuit variables combined. 
cases including a concurrence is also positive, suggesting an association with publication, but one that does not reach significance.

Notably, after controlling for other variables, the court's outcome (for or against the union) no longer shows a significant association with publication. The bivariate association between those variables is due not to the courts' desire to publish cases favoring employers, but to their tendency to publish reversals combined with the disproportionate number of appealed Board decisions favoring the union. ${ }^{75}$

Table VI: Logistic Regression for Publication: Case Characteristics and Issues $(\mathrm{N}=1139.76)$

\begin{tabular}{|c|c|c|c|}
\hline Variable & Coefirient & Robust Std. Errox & Sernifunne \\
\hline Reversal & 2.5259 \#\# & .4344 & .000 \\
\hline CA For Union & .2539 & .4094 & .535 \\
\hline Dissent & $2.0398 \star \star \star$ & .6399 & .001 \\
\hline Concurrence & 2.0675 & 1.3394 & .123 \\
\hline 8(a)(5) Issue & $.8911 * \star \star$ & .2800 & .001 \\
\hline 8(b) Issue & $1.7709 \star \star \star$ & .5382 & .001 \\
\hline 10(c) Issue & .0409 & 3686 & .912 \\
\hline Procedural Issue & 1.0068 * & .5338 & .059 \\
\hline Successor Issue & $-1.2405 *$ & .7523 & .099 \\
\hline Jurisdictional Issue & -.2727 & .5986 & .649 \\
\hline Multiple Issues & .1846 & .2845 & .516 \\
\hline Year of Decision & -.0565 & .0633 & .372 \\
\hline D.C. Circuit & .6507 & .4664 & .163 \\
\hline 1st Circuit & .7745 & 1.0035 & .440 \\
\hline 2d Circuit & .1265 & .4659 & .786 \\
\hline 3d Circuit & -.7322 & .5380 & .174 \\
\hline 4th Circuit & -.6253 & 6430 & .331 \\
\hline 5th Circuit & - .1008 & .5526 & .855 \\
\hline 7th Circuit & $2.9928^{\star \star \star}$ & .6950 & .000 \\
\hline 8th Circuit & $2.0325^{\star \star \star}$ & .7416 & .006 \\
\hline 9th Circuit & -.0009 & .4558 & .998 \\
\hline 10th Circuit & .4311 & .7094 & .543 \\
\hline 11th Circuit & .8691 & .6816 & .202 \\
\hline Constant & 3.3140 & 5.6938 & .561 \\
\hline Pseudo $\mathrm{K}^{2}$ & $.2750^{\star \star \star}$ & & 000 \\
\hline
\end{tabular}

75. Only $13.87 \%$ of the cases in our database reviewed a Board decision favoring an employer; the remaining $86.13 \%$ reviewed a decision that had favored the union. Because of this imbalance, a tendency to publish reversals also favors the publication of appellate decisions favoring employers. In a regression analysis using appellate pro-union outcome as the only independent variable, that variable showed a significant negative association with publication $(p=.000)$ and explained about $5.93 \%$ of the variance in publication. Adding a control for reversals, however, eliminated the significance of the coefficient for appellate outcome $(p=.206)$ and jumped the equation's explanatory power to $9.47 \%$. 
Cases including section $8(a)(5)$ or section $8(b)$ issues were significantly more likely to be published, after controlling for other variables, than were cases arising purely under section $8(a)(1)$ and (3). Remedial issues arising under section 10(c), on the other hand, showed no significant association with publication. Two of the three threshold issues showed a possible association with publication (ones that approached significance at the conventional .05 level), but these pointed in opposite directions. Cases resolving successor issues appeared less likely than other cases to be published, while those adjudicating other procedural issues seemed more likely to win publication. ${ }^{76}$ As in bivariate analyses, neither the resolution of multiple issues nor the year of decision showed a significant association with publication.

Controlling for the case characteristics reflected in Table VI eliminated the significant coefficient for cases decided by the Third Circuit. Although that circuit published a much smaller percentage of its ULP decisions than did other circuits, case characteristics appear to explain much of that difference. ${ }^{77}$ The Seventh and Eighth Circuits, on the other hand, published significantly more of their cases than did the reference Sixth Circuit even after controlling for characteristics like reversal or presence of a dissent.

\section{Panel Characteristics}

In the next stage of our analyses, we examined nine different characteristics of the panels resolving each case: (1) the number of Democrats on the panel, (2) the number of women, (3) the presence of a minority judge, (4) the average age of the judges, (5) the presence of a district court judge, (6) the presence of an appellate judge from another circuit, (7) the number of judges who graduated from

76. Both of these tendencies appeared in bivariate analyses, see supra Table V, although only the former was significant there. Most cases (89.1\%) adjudicating successor claims also resolved section $8(a)(5)$ bargaining disputes. The latter cases, as Table VI reports, were significantly more likely than those involving solely section $8(a)(1)$ or (3) claims to be published. Within the category of section $8(a)(5)$ bargaining claims, however, cases raising successor challenges were significantly less likely than others to be published $(p=.004)$. After controlling for the presence of a section $8(a)(5)$ issue, therefore, the negative relationship between successor issues and publication remained.

77. Further investigation revealed that the Third Circuit was extraordinarily deferential to the NLRB; that circuit reversed only 7\% of the ULP cases it heard, while other circuits reversed $24 \%$ of the cases coming before them $(p=.0002)$. Once we controlled for reversals, the Third Circuit's publication rate did not differ significantly from that of the reference Sixth Circuit. The Third Circuit, however, remained unusual in its low publication rates. After controlling for several additional variables, this coefficient again achieved significance. See infra note 81. 
an elite law school, (8) the number who had NLRA experience representing management clients, and (9) the number with other types of NLRA experience. ${ }^{78} \mathrm{We}$ added these variables to the regression equation reflected in Table VI; Table VII reports our results.79

The explanatory power of this equation is somewhat higher than that of the equation reported in Table VI, suggesting that panel characteristics contribute modestly to publication decisions. ${ }^{80}$ Only two panel characteristics, however, are significant, with the coefficient for a third characteristic approaching significance. Panels with more graduates of elite law schools were significantly more likely to publish their opinions, after controlling for other factors, than were panels with graduates of less prestigious law schools. Panels including more judges with pre-judicial experience representing management clients in NLRA cases, on the other hand, were significantly less likely to publish their opinions than were

78. As noted above, we tested numerous other judicial characteristics in the equation, but none achieved significance. See supra note 60 . We focus here on the agtregate characteristics of three-judge panels. In theory, it would be interesting to explore the relationship between publication decisions and the attributes of the judge authoring each published and unpublished opinion. Unfortunately, however, most unpublished dispositions do not reveal their author; among the unpublished dispositions in our database, only twenty-six of the 179 unweighted decisions identified an individual author. See also 1999 ANNUAL REPORT, supra note 1, at 49 tbl. S-3 (reporting that 3,951 unpublished opinions were signed in 1999, while 16,818 unpublished opinions were unsigned that year). The composite panel effects we explore here, moreover, would hold even if we were able to control for the identity of each opinion's author. Over time, each judge sits with every other judge from his or her circuit. In a large database like ours, innluences of authoring judges are thus randomly distributed. Accordingly, we can explore the impact of composite panel characteristics without controlling for the identity of opinion authors.

It might also be worthwhile to explore any relationship between publication and attributes of the presiding judge on each panel. That judge can be deduced from each judge's year of appointment and active/senior status. We hope to pursue any such relationships in future research. Again, however, any effects attributable to the presiding judge on each panel would not undermine the composite panel effects we identify here; over time, each judge sits with a variety of presiding judges within the circuit.

79. This regression equation excludes three sampled affirmances, representing 10.31 cases, because we could not identify the judges sitting on those panels. With missing values for all of the panel characteristics on those cases, we excluded them from the analyses in Tables VII, VIII, and IX.

We are unaware of any other scholars who have attempted to study systematically the relationship between judicial characteristics and publication. Several scholars, however, have documented the fact that some individual judges publish significantly more opinions than their colleagues. See Gulati \& McCauliff, supra note 4, at 198-201; Songer, supra note 6, at 312-13; Wald, supra note 2 , at 1376 .

80. A regression equation including only panel characteristics, without case characteristics and circuit dummies, contained no significant coefficients and was not itself significant $(p=.2346)$. The impact of these panel characteristics, therefore, is considerably more modest than that of case characteristics or circuit practices. Controlling for the latter variables, moreover, is necessary to illuminate the role of panel characteristics. Nevertheless, as Table VII shows, three of these characteristics do play a significant role in predicting publication. 
other panels. Panels with a higher average judicial age seemed more likely to publish their opinions, but this relationship merely approached significance. ${ }^{81}$

Table VII: Logistic Regression for Publication: Panel Characteristics (N=1129.45)

\begin{tabular}{|c|c|c|c|}
\hline Variable & Coefficient & Robust Std. Error & Significance \\
\hline Reversal & $2.7073^{\star \star \star}$ & .4872 & .000 \\
\hline CA For Union & .3832 & .4582 & .403 \\
\hline Dissent & $1.7498^{\star \star \star}$ & .6693 & .009 \\
\hline Concurrence & 1.9509 & 1.3039 & .135 \\
\hline 8(a)(5) Issue & $.9022^{\star \star \star}$ & .2983 & .002 \\
\hline 8(b) Issue & $1.9673^{\star \star \star *}$ & .6247 & .002 \\
\hline 10(c) Issue & -.0543 & .3768 & .886 \\
\hline Procedural Issue & $1.0055^{\star}$ & .5764 & .081 \\
\hline Successor Issue & $-1.5255 * *$ & .7415 & .040 \\
\hline Jurisdictional Issue & -.3504 & .5689 & .538 \\
\hline Multiple Issues & .3957 & .3021 & .190 \\
\hline Year of Decision & $-.1194 *$ & .0713 & .094 \\
\hline Democrats & $\cdot .2771$ & .1912 & .147 \\
\hline Women & .3054 & .2868 & .287 \\
\hline Minority Judge & .0161 & .3133 & .959 \\
\hline Average Age & .0477 * & .0281 & .089 \\
\hline District Ct Judge & .4188 & .3530 & .235 \\
\hline Visiting Judge & .1022 & .5885 & .862 \\
\hline Elite Law Grads & $.6939 \star \star \star$ & .1822 & .000 \\
\hline NLRA Mgmt & $-.6322 * \star$ & .2523 & .012 \\
\hline Other NLRA & .3660 & .3414 & .284 \\
\hline D.C. Circuit & .3205 & .5984 & .592 \\
\hline 1st Circuit & 1.0333 & 1.1815 & .382 \\
\hline 2d Circuit & -.1203 & .5155 & .815 \\
\hline 3d Circuit & $-1.0322^{\star}$ & .5973 & .084 \\
\hline 4th Circuit & - .3568 & .7066 & .614 \\
\hline 5th Circuit & .2718 & .5518 & .622 \\
\hline 7th Circuit & $3.5042^{\star \star \star}$ & .7727 & .000 \\
\hline 8th Circuit & $2.9150 * * \star$ & .7736 & .000 \\
\hline 9th Circuit & .2543 & .4665 & .586 \\
\hline 10th Circuit & .5171 & .7978 & .517 \\
\hline 11th Circuit & $1.4373 * \star$ & .6975 & .039 \\
\hline Constant & 4.8610 & 6.2110 & .434 \\
\hline Pseudo $R^{2}$ & $.3182^{\star \star \star}$ & & .000 \\
\hline
\end{tabular}

${ }^{*} \mathrm{p} \leq .10,{ }^{\star \star} \mathrm{p} \leq .05,{ }^{\star \star \star} \mathrm{p} \leq .01$

81. Controlling for these panel characteristics also revealed a possible relationship botweon the year of decision and publication; the likelihood of publication appeared to decline during tho seven years we studied, although that relationship merely approached significance. Controlling for panel characteristics also suggested that the Eleventh Circuit was more likely than the Sixth to publish opinions with similar characteristics. The negative coefficient for the Third Circuit also approached significance again in this equation. 
Other variables, including the number of women or Democrats on each panel, showed no significant association with publication in this regression. Our previous research suggested that Republican women resembled Democratic men and women in their tendency to support the union's legal position in ULP cases, ${ }^{82}$ so we experimented with combining our variables for Democrats and women into a single variable counting the number of Democrats or women on each panel. But the coefficient for this variable, like the separate coefficients for Democrats and women, failed to attain significance in the regression equation $(p=.312)$.

Similarly, we combined the variables for presence of a district court judge and presence of an appellate judge from another circuit to create a variable designating the presence of any "foreign" judge. Once again, however, the coefficient for this combined variable failed to achieve significance in our equation ( $p=.323$ ). Judicial attributes affecting publication decisions, at least when we consider panels as a composite, are limited to graduation from an elite law school, experience as a management attorney, and age.

\section{Strategic Behavior}

Some critics of limited publication plans charge that unpublished opinions allow judges to engage in strategic behavior. ${ }^{83} \mathrm{~A}$ judge favoring the union side in NLRA cases, for example, might publish pro-union decisions while leaving pro-employer opinions unpublished.84 Examining the relationship between panel characteristics and overall publication rates, as we did in the previous section, might not uncover evidence of this type of behavior.

To probe the possibility that strategic decisions affect publication, we divided our ULP cases into two groups: those in which the court of appeals favored the union and those in which the court

82. See Brudney, Schiavoni, \& Merritt, supra note 11, at 1756-59.

83. See, e.g., Gulati \& McCauliff, supra note 4, at 192-93; Reynolds \& Richman, NonPrecedential Precedent, supra note 6, at 1201. Scholars have also extensively debated the possibility of strategic behavior in judicial voting. See infra note 101 and accompanying text.

84. Even judges have noted the possibility of such strategic behavior. Sce, e.g., Philip Nichols, Jr., Selective Publication of Opinions: One Judge's View, 35 AM. U. L. REv. 909, 925 (1986) (Tf dissenting myself, I would never so insist [on publication]: it would result in making the decision I objected to precedential instead of nonprecedential, under Rule 18, and I would be 'bound' by it afterwards."); Wald, supra note 2, at 1374 ("I have even seen wily would-be dissenters go along with a result they do not like so long as it is not elevated to a precedent. We do oceasionally sweep troublesome issues under the rug, although most will no* stay put for long."). 
favored the employer. ${ }^{85}$ We then replicated the regression equation from Table VII for each subpopulation, omitting the variable for case outcome. ${ }^{86}$ Table VIII compares the results in each subpopulation with our results from the full population.

Table VIII suggests that strategic behavior has little impact on publication decisions. Political party affiliation, a variable that has been quite robust in predicting case outcomes in both our work and other studies of judicial behavior ${ }^{87}$ was not significant in predicting publication in any of the three equations. Panels with more Democrats showed no tendency to publish pro-union results, nor did they show any inclination to suppress cases rejecting union claims. ${ }^{88}$ The variable for gender also failed to achieve significance in any of our equations, despite previous findings that Republican women (like Democrats) favor union outcomes on appeal. ${ }^{89}$

85. Only a few cases included mixed results. We grouped those cases with pro-employer outcomes because the modal result in ULP'cases favors unions. See supra note 42 . We viowed any decision in favor of the employer, therefore, as a pro-employer outcome.

86. We also had to omit a few variables from each equation because those variables com. pletely predicted publication in the subpopulation. For cases decided by the courts of appeals in favor of the union, all opinions including a concurrence and all cases deciding section $8(b)$ claims were published. For cases rejecting union claims, all cases decided by the First, Tenth, and Eloventh Circuits were published. We omitted both these variables and the cases reflecting their characteristics from our analysis of the relevant subpopulation. See 2 STATA REFERENCE MANUAL RELEASE 6, at 232-34 (1999).

To ease interpretation, Table VII omits results for the circuit dummy variables. Except as noted in the previous paragraph, however, we included those dummies in our equations. Full results are on file with the authors.

87. See Brudney, Schiavoni, \& Merritt, supra note 11, at 1737.41; id. at 1689-92 (collecting studies).

88. Indeed, the coefficient in our equation for pro-union cases was negative, suggesting that any tendency among Democrats was a counter-strategic one of publishing fewer pro-union rosults.

89. Brudney, Schiavoni, \& Merritt, supra note 11, at 1719-20. As with our main regression analysis, we also created a variable counting the number of Democrats and women on each panel. This combined variable, like the separate ones reported in Table VIII, failed to achieve significance in the regression for either subpopulation.

Three other judicial characteristics displayed a significant association with outcomes in ULP cases but also failed to show any relationship with publication decisions. Graduates of selective colleges, as well as judges appointed more recently to the bench, reject union claims significantly more often than their colleagues, while judges with elected office experience accept those claims significantly more often. See Brudney, Schiavoni, \& Merritt, supra note 11, at 1715-16 tbls. II \& III. These three variables, however, never showed any significant association with publication decisions. Indeed, they displayed so little relation to publication that we eliminated them from the equations reported in this Article. 
Table VIII: Logistic Regression for Publication: Strategic Behavior

\begin{tabular}{|c|c|c|c|c|c|c|}
\hline & Full Populatio & & For Union & & Agange Un & \\
\hline Variable & Coeff. & Sig. & Coefi. & Sig. & $\cos \operatorname{ton}^{-}$ & $\$ 10$ \\
\hline Reversal & $2.7073 * \star \star$ & .000 & $2.9645 \star \star \star \hbar$ & .000 & 2.7980 *t & .000 \\
\hline CA For Union & .3832 & .403 & $\#$ & & $\#$ & \\
\hline Dissent & $1.7498^{* * *}$ & .009 & 2.8555 & .060 & 1.5250 & .031 \\
\hline Concurrence & 1.9509 & .135 & $\#$ & & .4931 & .782 \\
\hline $8(a)(5)$ Issue & $.9022^{\star \star \star}$ & .002 & $1.1211^{\text {t*k }}$ & .007 & .3411 & .505 \\
\hline 8(b) Issue & $1.9673^{* * *}$ & .002 & $\#$ & & 1.3429 & .124 \\
\hline 10(c) Issue & -.0543 & .886 & .2655 & .605 & -.7517 & .193 \\
\hline $\begin{array}{l}\text { Procedural } \\
\text { Issue }\end{array}$ & $1.0055 *$ & .081 & 1.1391 & .117 & .1864 & .846 \\
\hline Successor Issue & $-1.5255^{* *}$ & .040 & -1.3496 & .111 & -1.4275 & .220 \\
\hline Jurisdict. Issue & -.3504 & .538 & .0638 & .942 & -.7617 & .390 \\
\hline Multiple Issues & .3957 & .190 & .6312 & .141 & .4118 & .380 \\
\hline Year of Decision & $-.1194^{\star}$ & .094 & -.1656 & .108 & -.1273 & .244 \\
\hline Democrats & -.2771 & .147 & -.4195 & .123 & .1181 & .688 \\
\hline Women & .3054 & .287 & .5263 & .180 & .4284 & .433 \\
\hline Minority Judge & .0161 & .959 & .4005 & .335 & -.6671 & .204 \\
\hline Average Age & $.0477 \star$ & .089 & $.0917 *$ & .019 & -.0270 & .509 \\
\hline $\begin{array}{l}\text { District Ct } \\
\text { Judge }\end{array}$ & .4188 & .235 & .3819 & .422 & .6935 & .224 \\
\hline Visiting Judge & .1022 & .862 & .3592 & .674 & -1.0534 & .117 \\
\hline Elite Law Grads & 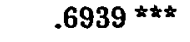 & .000 & $1.1782^{\star \star \star}$ & .000 & -.2149 & .431 \\
\hline NLRA Mgmt & $-.6322^{* \star}$ & .012 & $-.8643^{* \star}$ & .012 & -.2456 & .466 \\
\hline Other NLRA & .3660 & .284 & .2212 & .651 & .2597 & .675 \\
\hline Constant & 4.8610 & .434 & 5.5915 & .531 & 11.4809 & .213 \\
\hline$N$ & 1129.45 & & 752.21 & & 331.66 & \\
\hline Pseudo $\mathrm{R}^{2}$ & $.3182^{\star \star *}$ & .000 & $.3191 * t$ & .002 & .3011 * & 013 \\
\hline
\end{tabular}

${ }^{\star} \mathrm{p} \leq .10,{ }^{\star \star} \mathrm{p} \leq .05,{ }^{\star \star \star} \mathrm{p} \leq .01$

\# See note 86 and accompanying text

Just three coefficients in Table VIII signal the possibility of strategic behavior. The coefficients for average age, number of elite law school graduates, and number of former management attorneys-all of which achieved or approached significance in our main equation-were also significant in the equation for cases favoring the union. None of these three coefficients, on the other hand, was significant in the equation for cases rejecting union claims; indeed, the signs for two of those coefficients are opposite from the signs for the same coefficients in the other two equations. ${ }^{90}$ It appears, there-

90. We recognize that the regression for cases rejecting union claims embraces a substan. tially smaller sample than the regression for cases favoring the union or the regression for all cases combined. Sample size affects significance calculations, so one cannot simply compare significance levels across analyses performed in different-sized samples. Sce, e.g., PERRY R. HiNTON, STATistics ExPLAINED: A GUIDE FOR SOCLAL SCIENCE STUDENTS 97-99 (1995) (explaining how an increase in sample size increases the significance of results); IVY LEE \& MiNako MAYKOVICH, STATISTICS: A TOOL FOR UNDERSTANDING SOCIETY 383 (1995) (Without taking into account sample size, the same level of significance does not imply the same degree of association. 
fore, that older judges and graduates of elite law schools are more likely to publish pro-union opinions than their colleagues, but do not differ from other judges in their tendency to publish cases rejecting union claims. Similarly, it seems that judges with NLRA management experience are less likely than their colleagues to publish opinions favoring the union, while matching their colleagues in their inclination to publish cases rejecting union claims. Do these publication decisions occur because older judges and elite law graduates favor unions, while former management attorneys disdain union claims?

Such an interpretation of Table VIII is plausible, but we find ample grounds to reject it. To begin with, a strategic interpretation of Table VIII conflicts with other information about the behavior of older judges and graduates of elite law schools in ULP cases. When we analyzed judicial outcomes in all ULP cases, we found no tendency for elite law school graduates to favor the union in their votes. ${ }^{91} \mathrm{~A}$ strategic interpretation of Table VIII would require the inference that these judges favor the union in their decisions to publish, although they do not prefer the union in their decisions on the merits. Even more tellingly, our analysis of judicial votes revealed that older judges were significantly more likely than their younger colleagues to reject union claims. ${ }^{92}$ A strategic interpretation of Table VIII, therefore, would force the assumption that older judges favor employers with their votes but then, somewhat perversely, prefer publication of decisions supporting unions.

In addition, nonstrategic preferences readily explain the publication trends we identified among older judges and graduates of elite law schools. Older judges are most likely to have graduated from law school, and begun their legal careers, at a time when the courts of appeals published a substantial majority of their dispositions. These older judges may attach a higher value to publication than their younger colleagues; for them, publication itself may seem more routine. Elite law schools, meanwhile, may breed a special respect for law as a public institution or for the development of le-

Only when sample sizes are the same does a higher level of significance mean a strongor rolationship."). This concern particularly affects interpretation of the coefficients for judges with NLRA management experience. See infra note 100 and accompanying text. The contrasting coefficients for elite law graduates and older judges, however, raise at least the possibility of strato. gic behavior.

91. See Brudney, Schiavoni, \& Merritt, supra note 11, at 1715 tbl. II.

92. See id. at 1754 n.238. 
gal principles through case-by-case decision-making. ${ }^{93}$ On a less flattering note, graduates of these schools also may possess a sense of self-importance predisposing them to publication..$^{94}$ Either of these factors would produce higher publication rates among panels that include more graduates of elite institutions.

The composition of ULP cases reaching the courts of appeals, furthermore, explains why these nonstrategic preferences for publication manifested themselves most heavily among pro-union affirmances. As reported above, the union prevailed before the NLRB in the overwhelming majority of ULP cases decided by the courts of appeals. ${ }^{95}$ All circuits, moreover, published a large fraction of cases reversing NLRB decisions. ${ }^{96}$ Accordingly, judges exercised the most discretion over publication in pro-union affirmances. Those cases constituted more than two-thirds (67.09\%) of their ULP docket and were also the most underpublished category. ${ }^{97}$ The neutral preferences for publication we posit among older judges and graduates of elite law schools would therefore appear as an inclination to publish pro-union results.

Only in the case of former management attorneys is it possible to construct a strategic interpretation of Table VIII that is consistent with other information about those judges. Former management attorneys, somewhat surprisingly, are significantly more likely than judges with no NLRA experience to vote for union

93. See generally William N. Eskridge, Jr. \& Philip P. Frickey, An Hislorical and Crilical Introduction to The Legal Process, in HENRY M. HART, JR. \& ALBERT M. SACKS, THE LEGAL PROCESS: BASIC PROBLEMS IN THE MakTNG AND APPLICATION OF LAW li, xc-xciii, c-ciii (1994) (reporting that the legal process movement, emphasizing a judicial duty to engage in "reasoned elaboration" of "principles," was led in the 1950s by Professors Hart, Sacks, and Fuller of Harvard Law School, as well as Professor Wechsler at Columbia Law School, and that most elite law schools either used Hart and Sacks' materials in their courses or doveloped their own materials based upon the Hart and Sacks model).

94. Judge Wald's observation about former academics on the bench, that they "may feel irresistibly driven to communicate their intellectual processes and products to the world," could apply as well to graduates of elite law schools. Wald, supra note 2 , at 1372 . It is noteworthy, however, that we found no significant association between experience as a full-time academic and publication decisions.

95. See supra note 42.

96. Nationwide, the courts published $85.04 \%$ of their reversals in ULP cases. See supra Table V. Except for the Fourth Circuit (which published just 57.6935 of its ULP reversals), the Ninth (which published 70.59\%), and the Sixth (which published 73.21\%), all of the circuits published more than $85 \%$ of their ULP reversals. Indeed, the First, Second, Tenth, and Eleventh Circuits published $100 \%$ of those cases.

97. Courts published only $42.64 \%$ of affirmances favoring the union. In contrast, they published $57.97 \%$ of affirmances favoring the employer, 84.685 of reversals favoring the union, and $87.88 \%$ of reversals favoring the employer. 
claims. ${ }^{98}$ It is conceivable, however, that those judges prefer not to publish such results. Their familiarity with the NLRA might incline them to support pro-union outcomes compelled by that statute, while their sympathy for management positions might persuade them to withhold some of those results from publication and its accompanying precedential value.

The docket bias described above, however, affects publication decisions by former management attorneys just as it affects those decisions by other judges. The ULP cases in which all judges have the most discretion to withhold or publish opinions are pro-union affirmances. Any neutral tendency to resist publication would appear among these pro-union cases, just as any neutral preference favoring publication would manifest itself there. The significant tendency of former management attorneys to resist publication of cases endorsing the union's position, therefore, is as likely to signal a uniform reticence to publish as one targeted specifically at prounion results.

The coefficient for panel members with NLRA management experience, moreover, is consistently negative in all three equations reported in Table VIII. This provides persuasive evidence that the relative reluctance of former management attorneys to publish ULP cases stems from operation of a neutral preference, rather than from strategic behavior in pro-union cases. The failure of the negative coefficient to reach significance in the equation for cases rejecting union claims could stem from the much smaller size of that sample compared with the other samples for which we performed regression analyses. ${ }^{99}$ The lack of statistical significance attached to that coefficient should not in itself establish strategic behavior.

Finally, as with older judges and graduates of elite law schools, we can readily identify a nonstrategic reason that might explain the apparent reluctance of former management attorneys to publish ULP opinions. Those judges have more experience implementing the NLRA than judges lacking a management

98. See Brudney, Schiavoni, \& Merritt, supra note 11, at 1741-42. We believe this tendency to favor union legal positions stems from a special familiarity with the increasingly anomalous tenets of labor law doctrine, a familiarity that breeds respect for the Act's modestly protective stance toward group action in the workplace. See id. at 1742-50.

99. As Table VIII shows, our primary regression embraced 1129 cases, while our regression for pro-union cases included 752. In contrast, the regression for cases rejecting union claims was limited to 332 cases. See also supra note 90 (discussing impact of sample size on significance levels). 
background. ${ }^{100}$ Applying the same circuit rules and guidelines as colleagues who are less versed in labor law, they may genuinely view a higher percentage of cases as routine and unworthy of publication. The negative association between publication and number of panel members with NLRA management experience, in sum, most likely stems from expertise rather than strategic conduct.

\section{E. Homogeneous Panels and Whistleblower Effects}

Some scholars of judicial politics speculate that homogeneous panels behave differently from heterogeneous ones. AllDemocrat or all-Republican panels, for example, may behave differently from panels combining judges of both political parties. ${ }^{101}$ Similarly, all-male and all-female panels could differ from panels including both men and women. If homogeneity matters in judging, it might play a particular role in making publication decisions. It is possible, for example, that judges who share similar characteristics, backgrounds, or attitudes might be more likely to agree that a case is unworthy of publication because its result is "obvious" than would judges from different backgrounds who agreed upon the case outcome but brought different attitudes to that decision. More cynically, judges who share common backgrounds or traits could tacitly agree to suppress unpalatable opinions by leaving them unpublished. The presence of a judge who differed in some important respect from the other panel members could serve as a "whistleblower," subtly compelling the others to publish an "obvious" or unpalatable decision. ${ }^{102}$

100. Although some judges had experience working exclusively for unions, government, or academia on NLRA matters, and the coefficient for judges with that experience was not signifi. cant in our analyses, judges with non-management NLRA experience had significantly less NLRA experience overall than their colleagues with management experience. Sce Brudney, Schiavoni, \& Merritt, supra note 11, at $1746 \&$ n.213.

101. See generally Frank B. Cross \& Emerson H. Tiller, Judicial Parlisanship and Obadience to Legal Doctrine: Whistleblowing on the Federal Courts of Appcals, 107 YALE LJ. 2155 (1998) [hereinafter Cross \& Tiller, Judicial Partisanship]; Richard LL Revesz, Environmental Regulation, Ideology, and the D.C. Circuit, 83 VA. L. REv. 1717 (1997); Richard L. Revesz, Ideology, Collegiality, and the D.C. Circuit: A Reply to Chief Judge Harry T. Edu'ards, 85 VA. I REv. 805 (1999); Emerson H. Tiller \& Frank B. Cross, A Modest Proposal for Improving American Justice, 99 Coltn. L. REv. 215 (1999); Emerson H. Tiller \& Frank B. Cross, A Modest Reply to Judge Wald, 99 COLUM. L. REv. 262 (1999). For responses by prominent jurists to these assertions, see Harry T. Edwards, Collegiality and Decision Making on the D.C. Circuit, 84 VA. I. REv. 1335 (1998); Patricia M. Wald, A Response to Tiller and Cross, 99 CoLUds. L. REv, 235 (1999).

102. Professors Cross and Tiller gave the word "whistleblower" prominence in deseribing the behavior of politically heterogeneous panels of judges. See Cross \& Tiller, Judicial Partisanship, supra note 101, at 2159, 2175-76. 
The regression equations reported in Tables VII and VIII already contain some evidence that whistleblowers do not compel publication. Neither the presence of a district court judge nor that of an appellate judge visiting from another circuit increased the likelihood that an opinion would be published. If judges feel pressure to publish certain opinions in the presence of an "outsider," that pressure might materialize in the case of a judge who could carry tales of their strategic publication decisions to other courts. The failure of these variables to show a significant relationship with publication decisions provides modestly persuasive evidence against the whistleblower hypothesis in making publication decisions.

We tested the homogeneity theory further by creating a series of variables depicting homogenous panels and substituting those variables for the judicial characteristic variables in Table VII. Thus, we substituted variables representing all-Republican and allDemocratic panels for the variable counting the number of Democrats on a panel. We replaced the variable designating the number of women on each panel with one distinguishing all-male from mixed-gender panels. ${ }^{103}$ We similarly created variables for all-white panels; 104 panels composed exclusively of appellate judges from the circuit deciding the case; ${ }^{105}$ panels of all elite law school graduates; panels with no graduates of elite law schools; panels with no former NLRA management attorneys; 106 and panels with no judges who had other types of NLRA experience. ${ }^{107}$ To replace our variable for

103. Although several panels in our database included two female judges, none included all female judges. Thus, we could not construct a variable reflecting all-female panels.

104. This variable was simply the opposite of the variable reflecting presence of a minority judge. Because so few panels included two minority judges, the minority variable used for tho analyses in Tables VII and VIII distinguished panels with at least one minority judge from all other panels. There were no panels composed exclusively of minority judges, so we could not create a variable depicting that type of homogeneity.

105. Panels failing to meet this criterion were those including at least one district court judge or at least one judge visiting from another circuit. There were no panels composed exclusively of these "outsider" judges, so we could not create a variable representing that type of homogeneity.

106. Several panels included two former management attorneys, but none included threo judges with NLRA management experience. Thus, we could not create a variable reflecting panels with homogeneous management experience.

107. Once again, there were no panels composed exclusively of judges with union, gov. ernment, and/or academic NLRA experience, so we could not create a variable reflecting that type of homogeneity.

In addition to the two NLRA variables described above, we created two other variables roflecting panels with no type of NLRA experience (management, government, union, or academic) and panels composed exclusively of judges with some type of NLRA experience. These homogoneity variables, however, never achieved significance in our equations. 
average judicial age, we created two dummy variables reflecting panels with "young" or "old" average ages. ${ }^{108}$

Table IX reports the results of a regression equation substituting these homogeneity variables for the basic judicial characteristic variables. ${ }^{109}$ As the table shows, none of the homogeneity variables achieved significance at the conventional .05 level, and just two approached significance. The two approaching significance, moreover, reflect the effects already reported in Tables VII and VIII rather than distinctive effects based on homogeneity. Thus, panels composed exclusively of judges who had graduated from elite law schools were more likely to publish their opinions than were other panels. This, however, simply reflects the extreme instance of the tendency we detected in Tables VII and VIII for a higher number of elite law graduates to enhance the likelihood of publication. Similarly, the tendency of panels lacking any judges with NLRA management experience to publish their opinions represents an extreme instance of the lesson derived from Tables VII and VIII: a higher number of judges with NLRA management experience decreases the likelihood of publication.

108. To create these variables, we first ascertained that the full range of average panel ages spanned more than thirty years, from 43 to 74.33 years. We defined panels falling within the first ten years of this range as "young" panels, while panels falling in the oldest ten years were "old" panels. It is possible that some of these panels were heterogeneous with respect to age. A panel falling near the top of our "young" age range, for example, might have included two very young judges and one more senior judge. Likewise, panels falling in the reference "mid-age" category could have been completely homogenous. Within the current constraints of our data. base, however, this proved the best way to approximate homogeneous age panels.

109. We obtained similar results when we introduced the homogeneity variables one at a time into the regression equation, substituting just one homogeneity variable for its counterpart in the regression equation reflected in Table VII, while beeping the other variables in that equation constant. 
Table IX: Logistic Regression for Publication: Homogeneous Panels (N=1129.45)

\begin{tabular}{|c|c|c|c|}
\hline Variable & Coefficient & Robust Std. Error & Significance \\
\hline Reversal & $2.6580^{\star \star \star}$ & .4626 & .000 \\
\hline CA For Union & .3872 & .4329 & .371 \\
\hline Dissent & $1.9061^{\star \star \star}$ & .6467 & .003 \\
\hline Concurrence & $2.4155 *$ & 1.4497 & .096 \\
\hline $8(a)(5)$ Issue & $.9270 * \star \star$ & .2920 & .001 \\
\hline 8(b) Issue & $1.9713^{\star \star \star}$ & .5842 & .001 \\
\hline 10 (c) Issue & -.0305 & .3702 & .934 \\
\hline Procedural Issue & 1.0288 * & .5780 & .075 \\
\hline Successor Issue & $-1.3985 *$ & .7524 & .063 \\
\hline Jurisdictional Issue & -.4078 & .5592 & .466 \\
\hline Multiple Issues & .3419 & .2934 & .244 \\
\hline Year of Decision & -.0856 & .0679 & .208 \\
\hline All Republicans & .4412 & .3821 & .248 \\
\hline All Democrats & -.6287 & .5167 & .224 \\
\hline All Men & -.4462 & .3432 & 193 \\
\hline All White & .0604 & .3107 & .846 \\
\hline Young Panel & -.4390 & .4420 & .321 \\
\hline Old Panel & .2694 & .3360 & .423 \\
\hline All In-Cir. Judges & $\cdot .1530$ & .3208 & .633 \\
\hline All Elite Law Grads & $.5689 *$ & .3415 & .096 \\
\hline No Elite Law Grads & -.5600 & .5188 & .280 \\
\hline No NLRA Mgt & $.5320 *$ & .2897 & .066 \\
\hline No Nonmgt NLRA & $\cdot .5936$ & .3816 & .120 \\
\hline D.C. Circuit & .3510 & .5942 & .555 \\
\hline 1st Circuit & 1.4314 & 1.1743 & .223 \\
\hline 2d Circuit & .0201 & .4897 & .967 \\
\hline 3d Circuit & -.9046 & .5739 & .115 \\
\hline 4th Circuit & - .3719 & .6944 & .592 \\
\hline 5th Circuit & .1181 & .5556 & .832 \\
\hline 7th Circuit & $3.2469 * \star \star$ & .7847 & .000 \\
\hline 8th Circuit & $2.6136 * * \star$ & 8788 & .003 \\
\hline 9th Circuit & .2037 & .4780 & .670 \\
\hline 10th Circuit & .4174 & .7794 & .592 \\
\hline 11th Circuit & 1.0435 & .7140 & 144 \\
\hline Constant & 6.0202 & 6.0981 & .324 \\
\hline Pseudo $\mathrm{R}^{2}$ & $.3049 * \pi *$ & & .000 \\
\hline
\end{tabular}

${ }^{\star} \mathrm{p} \leq .10,{ }^{\star \star} \mathrm{p} \leq .05,{ }^{\star \star \star} \mathrm{p} \leq .01$

We recombined the homogeneity variables in Table IX in a variety of ways, but could find no other significant associations between homogeneous panels and the likelihood of publication. Com. bining the variables for all-Republican and all-Democratic panels into a single variable reflecting panels composed exclusively of judges from the same political party did not produce a significant association with publication. Nor did combining the variables for race and gender into a single variable distinguishing panels composed exclusively of white male judges result in such a significant 
association. ${ }^{110}$ In the end, we found no evidence that homogeneity affects the decision to publish an opinion.

\section{F. Are Unpublished Opinions Routine?}

The foregoing analyses all probed factors that might predict the likelihood that an opinion would be published. In this final Section, we explore a somewhat different empirical question: Are unpublished opinions themselves routine? Or is there any evidence that those opinions contain controversial decisions?

Our analyses already contain some evidence that unpublished opinions include controversy. As Table V reflects, courts declined to publish almost $15 \%$ of opinions carrying a dissent. Similarly, they refrained from publishing $14.96 \%$ of reversals and $5.92 \%$ of opinions with separate concurrences. Among the unpublished opinions, $7.15 \%$ were reversals, $1.85 \%$ carried dissents, and $0.19 \%$ included concurrences. In all, $8.44 \%$ of the unpublished opinions signaled some disagreement, either among the judges on the panel or between the court and the NLRB. ${ }^{111}$

We probe further the possibility of controversy by measuring whether judicial characteristics-such as political party, gender, college background, or pre-judicial experience-predict votes among unpublished opinions. Our previous work demonstrates that these judicial attributes help predict whether a judge will vote for the union in all ULP cases. ${ }^{112}$ Those associations suggest that labor law decisions do not mechanically follow precedent or statutory language; judges with different backgrounds and preferences sometimes interpret precedent or statutory language differently.

If unpublished opinions represent routine application of settled law, however, then judicial characteristics should show little or no relationship to outcome among those opinions. A Democrat, for example, should be just as likely as a Republican to vote against

110. We also combined the variables for difierent types of NLRA experience, see supra note 107, and broke apart the variable distinguishing panels with no judges sitting by designation into one variable designating panels with a visiting judge from another circuit, and a second variable reflecting panels with a district judge sitting by designation. None of these attempts yielded a significant association with publication rates.

111. The disagreement rate we found among unpublished opinions is somewhat similar to rates described by other scholars. Songer, for example, found that 5.935 of unpublished opinions in the Fourth Circuit during 1986 were reversals; 12.085 of those in the Eleventh Circuit were reversals; and $12.4 \%$ in the D.C. Circuit were reversals. Songer, supra note 6 , at 311 . Just 0.395 of the unpublished opinions in all three circuits included dissents. See id.

112. See Brudney, Schiavoni, \& Merritt, supra note 11, at 1715 tbl. II, 1737-59 (explaining results). 
the union in an unpublished opinion if that opinion truly represents the straightforward application of existing law. ${ }^{113}$ Indeed, several federal appellate judges recently have suggested that analysis of unpublished decisions would yield just such a result. ${ }^{114}$

We thus returned to a larger database recording all judicial votes on ULP issues to analyze whether the subset of unpublished opinions reflected any significant associations between judicial characteristics and judicial outcome. ${ }^{115} \mathrm{We}$ could not simply perform a regression analysis within the subset of unpublished decisions, because analyses in the previous sections show that judicial characteristics affect publication decisions. Limiting our analysis to unpublished opinions thus would introduce an unacceptable risk of selection bias. ${ }^{116}$

We solved this problem by using a probit model with sample selection. ${ }^{117}$ This model first uses one set of variables to predict an opinion's unpublished status, and then a second set of overlapping, but not identical, variables to predict judicial votes in unpublished opinions. Information from the first equation is used to correct for sample selection in the second equation.

Table X reports the results of a regression for judicial votes supporting the union; the regression is limited to the population of unpublished cases, after correcting for selection bias. ${ }^{118}$ As the table

113. See Songer, supra note 6, at 310 ("[T]aking the formal criteria [for publication] at faco value leads to the prediction that there will be no partisan or presidential appointment effects observable in the unpublished decisions of any of the circuits examined."). Songer used a similar technique to analyze unpublished opinions in his pathbreaking 1990 study, but ho limited his investigation to bivariate analyses and did not attempt to correct for selection bias. See id. at 312-13.

114. See, e.g., Edwards, supra note 101, at 1343; Wald, supra note 101, at 246.

115. For a detailed discussion of this database, see Brudney, Schiavoni, \& Merritt, supra note 11 , at 1694-1708.

116. For further discussion of selection bias and the problems it presents for social scienco analyses, see generally Richard A. Berk, An Introduction to Sample Selection Bias in Sociological Data, 48 AM. SoC. REV. 386 (1983); Christopher Winship \& Robert D. Mare, Models for Sample Selection Bias, 18 ANN. REV. Soc. 327 (1992).

117. We used the "heckprob" command within STATA Version 6. See 2 STATA REFERENCE MANUAL RELEASE 6, at 29-37 (1999).

118. In the selection equation, we used eight variables that were significant or approached significance in our direct analyses of publication (reversal, presence of a dissent, section $8(a)(6)$ issue, section $8(\mathrm{~b})$ issue, year of decision, judge's age, judge's graduation from an elite law school, and judicial experience representing management in NLRA cases), as well as two variablos (presence of a district court judge and presence of a concurrence) that came close to achieving significance and, we hypothesized, might have some previously undetected relationship to publi. cation. After running the analysis, we added to the selection equation several variables that wore significant in our primary prediction of judicial outcome (Democrat, year appointed, female, a female/Democrat interaction, Latino/Asian, prior elective office, nonelective office, prior judicial experience, and experience as a full-time academic). We added these variables to insure that 
reflects, five different judicial attributes show a significant association with votes even among unpublished opinions. Democratic judges were significantly more likely than their Republican colleagues to support the union in these unpublished cases. ${ }^{119}$ Judges who had held elected office or served as full-time academics were also more likely to vote for the union. Conversely, judges with prior judicial experience, as well as Latino and Asian judges, were significantly less likely to support the union. ${ }^{120}$

effects reflected in the main equation did not stem from selection bias. Indeed, coefficients for several of these variables lost significance after we corrected for that bias.

In our final equation, Rho (the sample selection statistic) was $-.8283(p=.000)$, indicating the presence of significant selection bias. Variables that showed a signuficant association with nonpublication were reversal, dissent, or concurrence, the gender/Democrat interaction, nonelective office, judicial experience, $8(\mathrm{a})(5)$ issues, $8(\mathrm{~b})$ issues, graduation from an elite law school, and NLRA management experience. This list differs somewhat from the variables we report as significant in Table VII, because it is based on an analysis of individual judicial votes on separate issues, rather than on analysis of cases. The latter analysis is more appropriate for isolating factors that predict publication, because cases are published in their entirety by panels, rather than by individual judges or individual issues. For the purpose of creating a selection equation, hovever, we had to analyze publication by judge and issue.

119. Songer likewise found a statistically significant relationship between political party and liberal outcomes in a database of unpublished opinions, although he relied exclusively upon bivariate analyses. See Songer, supra note 6, at 312. See generally Donald R. Songer, Consensual and Nonconsensual Decisions in Unanimous Opinions of the United States Courts of Appeals, 26 AM. J. POL. SCI. 225 (1982) (identifying ideological differences in cases disposed of unanimously by courts of appeals).

120. The significance of our coefficient for Asian and Latino judges should be interpreted with caution, because very few of those judges appeared in our database. Brudney, Schiavoni, \& Merritt, supra note 11, at 1703 n.103. 
Table X: Logistic Regression for Votes Favoring the Union in Unpublished Decisions $(\mathrm{N}=2, \mathrm{525})$

\begin{tabular}{|c|c|c|c|}
\hline Variable & Coefficient & Robust Std. Error & Significance \\
\hline Democrat & $.3967^{\star \star \star}$ & .1361 & .004 \\
\hline Year Appointed & .0138 & .0098 & .160 \\
\hline Age & -.0024 & .0074 & .751 \\
\hline Female & .2226 & .2689 & .408 \\
\hline Female/Dem. Int. & -.4800 & .3384 & .156 \\
\hline Black & -.2249 & .2652 & .396 \\
\hline Latino/Asian & - $1.0371^{\star \star \star}$ & .2771 & .000 \\
\hline Catholic or Jewish & -.0905 & .1076 & .400 \\
\hline College Selectivity & $\cdot .0080$ & .0054 & 138 \\
\hline Elite Law School & -.0977 & .1096 & .373 \\
\hline Elected Office & $.2901 \star \star$ & .1199 & .015 \\
\hline Nonelective Position & -.1307 & .1167 & .263 \\
\hline Judicial Experience & $-.3116 * \star *$ & .1118 & .005 \\
\hline Full-Time Academic & $.5438 \star \star \star$ & .1350 & .000 \\
\hline Corporate Law Exp. & .0844 & .1358 & .543 \\
\hline Workplace Law Exp. & -.0628 & .1511 & .678 \\
\hline NLRA Management & .1854 & .1784 & .298 \\
\hline Board Outcome & $1.9500 * \star \star$ & .1850 & .000 \\
\hline 8(a)(5) Issue & .0899 & .0948 & .343 \\
\hline Other 8(a) Issue & $-.6775 * \star \star$ & .2275 & .003 \\
\hline 8(b) Issue & 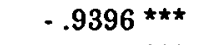 & .3128 & .003 \\
\hline 10(c) Issue & $-.3575^{\star \star \star}$ & .1173 & .002 \\
\hline D.C. Circuit & .0370 & .1644 & .822 \\
\hline 1st Circuit & $3.4990 * \star \star$ & .2148 & .000 \\
\hline 2d Circuit & $1.3600 * * *$ & .2164 & .000 \\
\hline 3d Circuit & $.5719 \star \star \star$ & .1641 & .000 \\
\hline 4th Circuit & 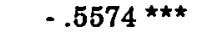 & .1467 & .000 \\
\hline 5th Circuit & - .2032 & .1931 & .293 \\
\hline 7th Circuit & -.1645 & .2261 & .467 \\
\hline 8th Circuit & -.1494 & .2887 & .605 \\
\hline 9th Circuit & .2430 & .1665 & .144 \\
\hline 10th Circuit & $3.2813 * \star \star$ & .1281 & .000 \\
\hline 11th Circuit & $3.4671 * \star \star$ & .1695 & .000 \\
\hline Year of Decision & $-.0778^{* * *}$ & .0209 & .000 \\
\hline Constant & $6.5803^{\star \star \star}$ & 1.8502 & .000 \\
\hline Model Chi ${ }^{2}$ & $4308.95 * * *$ & & .000 \\
\hline
\end{tabular}

${ }^{\star} \mathrm{p} \leq .10,{ }^{\star \star} \mathrm{p} \leq .05,{ }^{\star \star \star} \mathrm{p} \leq .01$

These significant relationships strongly suggest that resolution of unpublished cases is not as straightforward as some judges maintain. If these opinions represent uncontroversial applications of the law to new fact patterns, why do judges with different backgrounds and demographic characteristics reach different results? We address that question further in the next Section.

In addition to the five judicial background characteristics approaching or reaching significance in this equation, the coeffi- 
cient for year of decision is negative and strongly significant. More recent unpublished decisions, in other words, were more likely to reject union claims than older decisions. This relationship could reflect doctrine that became progressively less sympathetic to union positions, but we did not detect such a relationship in our analysis of all judicial votes in both published and unpublished opinions.121 The emergence of this relationship solely among unpublished cases, and over a relatively short period, again suggests that the opinions may represent more discretionary application of legal principles than the publication rules contemplate.

\section{DIScUSSION}

Our analysis of publication decisions and unpublished opinions yields results that are in some respects reassuring and in others more worrisome. We address the contrasting implications of our findings in the discussion that follows. In a final Section, we consider the relationship of these findings to the Eighth Circuit's recent decision holding that the Constitution requires Article III courts to give precedential weight to all of their decisions. ${ }^{122}$

\section{A. Support for Limited Publication Rules}

We uncovered several indicia that existing publication plans function reasonably well. Formal publication criteria, such as a decision to reverse or the presence of a dissent, play a large role in predicting publication. In addition, circuits that formally encouraged publication of reversals published more decisions, on average, than other circuits.

It is also reassuring that different statutory sections helped predict publication. Courts were more likely to publish opinions disposing of section $8(a)(5)$ bargaining claims, as well as cases reviewing section $8(\mathrm{~b})$ allegations against unions, than they were to publish cases dealing exclusively with the bread-and-butter claims of intimidation or discrimination against individual employees that arise under sections 8(a)(1) and (3) of the NLRA. The latter claims, which involve assertions of individual rights analogous to claims in other areas of public law, may seem more familiar to judges than

121. See Brudney, Schiavoni, \& Merritt, supra note 11, at 1715 tbl. II. We also found no such relationship when analyzing published judicial votes on their own. See id. at 1732 tbl.VII.

122. Anastasoff v. United States, 223 F.3d 898 (8th Cir. 2000); see also supra notes 8.9 and accompanying text (discussing Anastasoff). 
allegations of bad faith bargaining under section $8(a)(5)$ or union misconduct under section $8(b)$, which raise relatively unusual questions about the protected nature of group action. ${ }^{123}$ Decisions to publish more cases discussing the latter issues, therefore, track the intent of circuit plans to limit publication to cases that "add to the body of law."124

Similarly, we found a significant association between the number of ULP cases decided by a circuit and the likelihood that an opinion rendered in that circuit would be published. After controlling for other variables, circuits that decided a greater number of ULP cases published a smaller fraction of those cases. As one would expect, the marginal precedential value of each case was smaller in circuits that decided a large number of such cases.

We found no evidence of any whistleblower effects in publication decisions. Homogeneous panels were just as likely to publish their opinions as heterogeneous ones. Political party affiliation, moreover, played no role in selecting cases for publication. Nor did a host of other judicial attributes affect the likelihood that an opinion would be published. We thus found few traces of partisan politics or strategic behavior in choosing cases for publication.

The only personal characteristics showing a significant link with publication-judicial age, graduation from an elite law school, and NLRA management experience-most likely stemmed from neutral publication preferences rather than strategic conduct. Indeed, if we are correct that the association between management experience and restrained publication stems from expertise, then the association further confirms the rational working of limited publication plans. The judges with most experience interpreting the NLRA were least likely to publish adjudications under the Act, suggesting that they recognized routine or redundant decisions.

\section{B. Warning Signals}

Notwithstanding the reassuring results discussed above, we uncovered evidence that raises troubling questions about limited publication rules. Like other scholars, we identified substantial differences in publication rates among the circuits. This variation arose in a relatively compact area of law and even after we controlled for caseload and numerous other factors. Judges from differ-

123. See Brudney, Schiavoni, \& Merritt, supra note 11, at 1726-27.

124. See supro note 20 and accompanying text. 
ent circuits apply relatively similar publication criteria to arrive at widely different publication rates. This lack of uniformity suggests that judges do not make consistent publication decisions. ${ }^{125}$

Intercircuit variation also means that some circuits shape precedent more than others. High publication rates in the Seventh and Eighth Circuits, even after controlling for factors like reversals and dissents, may mean that those circuits exert greater influence on the development of the law governing unfair labor practices. ${ }^{126}$ This phenomenon raises particular concern under a nationwide statute like the NLRA, in which each party has considerable discretion to choose the venue for appeal of a Board decision. ${ }^{127}$ Indeed, the Board and other repeat players in the NLRA litigation arena may decide to factor in the publication records of particular circuits when selecting their appellate forum, if they have not already done so.

Second, we found a surprising number of reversals, dissents, and concurrences among unpublished opinions. About one in fourteen unpublished opinions (7.15\%) reversed the NLRB, while $2.04 \%$ included a concurrence or dissent. Some of those reversals and split opinions may have marked only minor disagreements with the Board or among panel members; we coded cases as reversed or split if the court reversed the Board on any issue or if a panel member wrote a separate opinion on any matter. Still, several scholars have argued that courts should publish all, or virtually all, reversals and split opinions. According to critics, these decisions "are, by definition, controversial" because they mark disagreement among learned judges and/or agency members. ${ }^{128}$ Concurrences and dissents may

125. Judges have expressed the belief that "it [is] probable that a like case would usually" be published, or not published, similarly in all circuits." Nichols, supra note 5, at 922. The disparity in circuit publication rates, especially after controlling for factors like reversals and dissents, casts doubt on this assertion.

126. Cf. Gulati \& McCauliff, supra note 4, at 191-92 (noting that intercircuit differences in the use of judgment orders can create differences in influence). Gulati and McCaulifi go so far as to argue that, given intercircuit differences in publication rates, “a President making a nomination to a Court of Appeals should realize that appointing someone to the Seventh Circuit, which has a high rate of publication, will have a significantly different impact than appointing the same person to the Third Circuit." Id. at 205.

127. See 29 U.S.C. § 160(f) (1994) (allowing persons aggrieved by a Board order to obtain review in the circuit where the unfair labor practice allegedly occurred, where the aggrieved person resides or transacts business, or in the D.C. Circuit); id. $\$ 160(\mathrm{e})$ (allowing the Board to seek enforcement of its order in the circuit where an unfair labor practice occurred, or where the person that committed the ULP resides or transacts business).

128. Reynolds \& Richman, Price of Reform, supra note 6, at 612 (discussing split opinions); see also id. at 618 (discussing reversals); Songer, supra note 6 , at 309.10 ('T]t should be expected that virtually all of the unpublished decisions will be unanimous affirmances of the case below. If the case involves ... the straightforward application of clear and well sattled 
also "serve to restrain judicial advocacy," 129 while reversals illuminate misunderstandings or misperceptions by agencies or district courts-or even ongoing substantive disagreement between those decision-makers and the courts of appeals. ${ }^{130}$ Nonpublication of reversals, concurrences, or dissents above a de minimis level compromises all of these functions.

Third, we noted that circuit rules permitting citation of unpublished opinions were associated with lower publication rates. This relationship is not necessarily worrisome; it may signal a rational belief that if unpublished opinions are citable, there is less harm in leaving a decision unpublished. The relationship, however, may constitute an unforeseen effect of more lenient citation rules in some circuits. Courts contemplating a change in their citation rules will have to weigh the possibility that citation practices affect publication rates. Similarly, if other courts of appeals-or the Supreme Court-agree with the Eighth Circuit that the Constitution accords precedential effect to all unpublished opinions, the percentage of opinions that are published may fall in circuits that currently forbid citation of unpublished opinions. ${ }^{131}$

Fourth, we discovered that three judicial characteristics were significantly associated with publication rates: older panels and those with a greater number of elite law school graduates published a higher number of their opinions, while panels with more

precedent..., then the correct decision and the correct basis of decision should be obvious to any person who is well trained in the law.").

129. Reynolds \& Richman, Price of Reform, supra note 6, at 612.

130. See id., at 618-19.

131. See Anastasoff v. United States, 223 F.3d 898, 900, 905 (8th Cir. 2000). The relation. ship, of course, does not necessarily carry this causal direction. It is possible that the circuits currently allowing citation of unpublished opinions adopted those rules precisely because they maintained a high percentage of unpublished opinions. The high rate of unpublished opinions could derive from other factors, while the citation rule responded to and reinforced that situa. tion.

We identified two other curious relationships between publication rates and circuit rules gov. erning publication. Circuits that encouraged publication of opinions carrying dissents or concurrences published a smaller percentage of their opinions than did circuits lacking that formal encouragement in their rules. After we controlled for other factors, we also found that circuits explicitly requiring majority approval to publish an opinion published more decisions, on average, than did other circuits.

These relationships, again, do not mean that limited publication plans are malfunctioningor even that the rules cause these fluctuations in publication rate. The rules may respond to publication practices already entrenched within each circuit. A circuit with low publication rates, for example, may adopt a rule encouraging publication of split opinions because of concorn that too many of those decisions are unpublished. The relationships, however, provide further evidence that practices beyond formal rules affect publication rates. Regardless of whether any of these associations are causal or merely reinforcing, limited publication rules may well have unexpected effects. 
former management lawyers published a lower percentage. As noted earlier, the last of these relationships could represent strategic behavior. Former management attorneys were significantly less likely than their colleagues to publish opinions favoring the unionprecisely those precedents that would have harmed their former clients. We believe this relationship arises instead from the management attorneys' greater expertise under the NLRA, and their consequent ability to identify more decisions as routine, ${ }^{132}$ but the possibility of strategic behavior remains.

Even if not strategic, the publication behavior affects the composition of precedential law. Ironically, the body of published ULP opinions contains proportionately fewer cases decided by the judges most familiar with the field. If expertise discourages publication in the manner we have suggested, and if the same tendencies occur in other fields, an unanticipated effect of limited publication plans would be a subtle bias toward published opinions by panels with less sophistication in the subject under review. ${ }^{133}$

All of the aforementioned effects have important implications for social scientists who study judicial decision-making. As other scholars have warned, the large percentage of unpublished opinions counsels against research based exclusively on published decisions. ${ }^{134}$ This is especially true if any of the factors under investigation plays a role in selecting cases for publication. ${ }^{135}$ Our own work shows that the tendency of elite law school graduates to publish significantly more ULP opinions than their colleagues, combined with the fact that opinions rated borderline for publication are likely to be pro-union affirmances, would lead a researcher

132. See supra note 100 and accompanying text.

133. Professors Gulati and McCauliff suggest an opposite scenario, that panels lacking expertise in a complex area-such as securities regulation-might avoid deciding difficult issues of first impression by issuing a summary affirmance. See Gulati \& McCauliff, supra note 4, at $176,189-90$. We found no evidence of this syndrome among ULP cases. On the contrary, as explained in text, less expert panels were more likely to publish than expert ones.

In contrast to the relative scarcity of published ULP opinions joined by former management attorneys, panels of older judges and elite law graduates contribute a disproportionately high fraction of those opinions. That skew may not worry policymakers, but it signals yet again that limited publication has unintended consequences.

134. See, e.g., Peter Siegelman \& John J. Donohue III, Studying the Iceberg from Ils Tip: A Comparison of Published and Unpublished Employment Discrimination Cases, 24 LAY \& Soct REV. 1133, 1136-37, 1165-66 (1990); Songer, supra note 6, at 307.

135. See also Siegelman \& Donohue, supra note 134, at 1145. Siegelman and Donohue quote Sir Arthur Eddington's wonderful words illuminating this subject: "I]f you catch fish with a net having a 6-inch mesh, you are liable to formulate the hypothesis that all fish are more than 6 inches in length." Id. at 1145 n.30. If judicial attributes systematically affect the selection of cases for publication, then studying published cases will yield a biased view of those attributes and their relationship to outcomes. 
analyzing only published opinions to the erroneous conclusion that graduates of elite law schools favor the union in their ULP votes. ${ }^{136}$ Similarly, a focus on published opinions would lead that researcher to overlook a significant association between age and anti-union votes. 137 Today, a scholar who studies only published opinions from the United States Courts of Appeals does so at his or her peril.

Finally, and most notably, we found evidence that five judicial characteristics predicted votes even among unpublished opinions. Judges appointed by Democratic Presidents, those who had held elected office, and those who had served as full-time academics were significantly more likely than other judges to support the union in these cases. Judges who had served on another court, as well as Latino or Asian judges, were significantly less likely to vote for the union in unpublished cases.

These findings suggest that unpublished opinions may not be as routine as advocates of limited publication believe. On the contrary, partisan and attitudinal differences emerge even among these cases. The differences, in turn, may signal important dissension over points of law. It is possible that, contrary to the intent of limited publication plans, some unpublished opinions create new law and that judges disagree over the direction of those legal principles.

It is also possible, however, that most unpublished opinions do apply settled law to the facts, but that judges differ in the way they apply that law. A Democratic judge may "see" a retaliatory motive behind an employer's disciplinary action, leading to a prounion vote in a ULP case, while a Republican judge does not see such a motive on the same facts. A judge who has held elected office may be more sensitive than other judges to conduct tainting elections; she may perceive a chill on freedom of employee choice when other judges fail to do so. Unpublished opinions thus could "decide particular cases on the basis of well-settled principles of law,"138 while still reflecting substantial disagreement among judges about how those principles should apply.

Panel unanimity in most unpublished opinions does not negate this possibility. Cases are most likely to appear routine when the law is clear and all three judges agree on the application of that

136. See Brudney, Schiavoni, \& Merritt, supra note 11, at 1733-35, 1751-52.

137. See id. at $1754 \mathrm{n} .238$. This occurs because the older judge's tendency to reject union claims, apparent in an analysis of all published and unpublished decisions, is masked by the older judge's tendency to publish more routine pro-union affirmances.

138. 5TH CrR. R. 47.5.1 (1993). 
law to the facts. Yet our examination of unpublished cases suggests that some unanimous panels apply the law in ways that favor the union while others apply it in ways that support the employer. Analyzing a large number of cases, as we did, can reveal such tendencies.

These findings raise important policy issues about limited publication. Even if unpublished opinions articulate no new principles, do differences in applying settled law to the facts merit more public attention? One could argue that these differences are inevitable as judges apply nuanced standards in complex factual settings, that a sufficient number of these differences already appear among published cases, and that it is unnecessary to inflate the body of published precedent with further examples of subtle variation in the way judges apply existing principles to the facts.

On the other hand, law consists largely of applying established principles to new facts. This is especially true under a mature statute like the NLRA, where many rules of law are well settled. If judges vary in predictable ways as they apply settled principles, litigants might benefit from being able to trace-and citethose variations. More broadly, federal court scholars and the general public might deserve to know the extent to which judges differ in their application of existing law. Our findings raise questions about unpublished opinions that seem thus far to have escaped attention. ${ }^{139}$

In this connection, it is especially troubling that the coefficient for year of decision was negative and strongly significant in our regression among unpublished cases. This variable did not achieve significance in our previous analyses of all ULP cases. ${ }^{140} \mathrm{It}$ appears, therefore, that unpublished ULP decisions increasingly rejected union claims between 1987 and 1993, while published opinions showed no such tendency. Litigants who relied exclusively on published opinions, therefore, may have received inaccurate signals about judicial trends. Even if the courts did not articulate new pro-employer principles during that period, they may have applied

139. Donald Songer captured the view of most policymalsers when he declared in $\mathbf{1 9 9 0}$ that "[t]here is little controversy over the abstract notion that cases with no precedential value, no significance for public policy, and in which the existence of clear precedents give judges no discretion in decisionmaking should not be published." Songer, supra note 6, at 309 . Songer and others seem not to have contemplated the possibility that even "clear precedents" might give judges some discretion in applying those principles.

140. See Brudney, Schiavoni, \& Merritt, supro note 11, at 1715 (Tablo II); see also id. at 1732 (Table VI) (reporting no significance for year of decision with regard to ULP issues among published cases). 
existing law in a way that increasingly favored employers. The circuits' limited publication practices would have masked that trend.

In sum, we identified numerous warning signals about the operation of limited publication plans. All of our findings, of course, are limited to unfair labor practice claims arising under the $\mathrm{Na}$ tional Labor Relations Act. Different relationships might emerge if we studied other fields of law. When exploring publication decisions, however, it is important to focus on relatively discrete legal areas. Otherwise, variation among fields-with some subjects generating high rates of publication and others producing few published decisions-could conceal important relationships. Further, the trends we uncovered are unlikely to affect only NLRA decisions. Table I confirms that the circuits vary dramatically, not only in the percentage of ULP cases they publish, but in their overall percentages of published decisions. Publication rates among the circuits for ULP decisions correlate strongly with overall circuit-by-circuit publication rates. ${ }^{141}$ Other results we uncovered in our analysessuch as the presence of partisan differences among unpublished decisions-are likely to occur in fields outside labor law as well.

\section{Should Unpublished Opinions Be Precedential?}

The Eighth Circuit recently sent shock waves through the legal community by ruling that Article III of the Constitution requires the federal courts to accord precedential status to unpublished opinions. ${ }^{142}$ The court's opinion-authored by Judge Richard Arnold-has triggered a constitutional debate that may be resolved by the Supreme Court. ${ }^{143}$ The outcome of that controversy will depend upon constitutional principles, especially the meaning of the phrase "judicial Power" in Article III of the Constitution. ${ }^{144}$ The

141. See supra text following note 61 .

142. See Anastasoff v. United States, 223 F.3d 898, 900, 905 (8th Cir. 2000); see also supra notes 8-9 and accompanying text (discussing Anastasoff).

143. See, e.g., Tony Mauro, Stealth Decisions Under Fire, LEGAL Times, Sept. 4, 2000, at 1 ("[T]he decision was the talk of the appellate world within hours. The next day, it dominatod hallway discussions at the 9th Circuit Judicial Conference in Idaho. Academics traded around the decision-and reactions to it-in online chats for days."); see id. at 6 ("En banc treatment or a grant of cert [by the Supreme Court] seem fairly likely, especially in light of the enormous practical consequences of what Arnold has done.") (quoting Harvard Law School Professor Lauronco Tribe). As of November 21, 2000, when this Article went to press, a petition for rehearing on banc was pending before the Eighth Circuit but had not yet been resolved.

144. The Eighth Circuit stressed that Article III vests only "judicial Power" in the fedoral courts. U.S. CONST. art. III, $\S 1$, cl. 1; Anastasoff, 223 F.3d at 899 . The court reasoned that this power-to determine what the law is through case-by-case decision-making-necessarily om- 
findings we present here do not determine that constitutional issue, but some of them offer valuable background.

In particular, we found that the unpublished opinions we studied included a surprising number of reversals, dissents, and concurrences. Even more important, we discovered that outcomes among unpublished opinions showed significant associations with political party affiliation, specific professional experiences, and other characteristics of judges adjudicating the cases. Together, these findings suggest that panels authoring unpublished opinions reach some results with which other reasonable judges would disagree. Such divergent views are likely to reflect both differences as to the meaning of legal principles and disagreement over the proper application of seemingly settled law. Under those circumstances, failing to give unpublished opinions precedential effect raises the very specter described by the Eighth Circuit: that like cases will be decided in unlike ways, that judges' decisions will be 'regulated only by their own [personal] opinions," 145 and that legal principles will evolve, not "in response to the dictates of reason," but "because judges have simply changed their minds." 146 Although courts may decide that maintaining a body of unpublished opinions is a practical necessity, our findings lend weight to the Eighth Circuit's concern that these decisions should carry the same precedential effect as other opinions.

In addition, our research confirms that circuits vary widely in the percentage of opinions they publish, even when analysis is limited to decisions arising under a single statute and when we control for separate factors that might affect publication (such as the presence of a reversal). Individual judges also seem to vary in their tendency to publish opinions after controlling for other factors. In our study, older judges and graduates of elite law schools showed a higher tendency to publish while judges who had represented management on NLRA matters were less inclined to publish their NLRA decisions. If unpublished opinions lack precedential value, then these patterns distort-probably unwittingly-the composition of opinions binding future decisions. Some circuits, and some judges, will determine the direction of authoritative case law more than others.

braces the doctrine of precedent, and that any attempt by an Article III court "to avoid the precedential effect of [its] prior decisions" is an unwarranted expansion of its power as a court. Id. at 900.

145. Anastasoff, 223 F.3d at 901 (quoting l BLACKSTONE, COMrEentaries *259 (1765)).

146. Id. at 905 . 
In concluding that the Constitution requires Article III courts to give all decisions precedential effect, the Eighth Circuit invoked Justice Story's warning that "[a] more alarming doctrine could not be promulgated by any American court, than that it was at liberty to disregard all former rules and decisions, and to decide for itself, without reference to the settled course of antecedent principles." ${ }^{147}$ Rules restricting the citation of unpublished opinions are not that arbitrary; they do not allow a court to look back at the accumulated body of decisions and decide for itself which ones to honor. Instead, limited citation rules have a prospective effect; they allow a panel to decide whether the case before it will bind judges in future cases. Courts will have to determine whether this practice is as worrisome as one allowing a court to "disregard all former rules and decisions" and, whatever that answer, whether the practice exceeds the "judicial Power" conferred by the Constitution.

Our research shows that publication decisions, when combined with limited-citation rules, do affect the substance of precedential law. Unpublished decisions do not reflect routine applications of existing law with which all judges would agree. If they did, these decisions would not include a noticeable number of reversals, dissents, or concurrences, nor would they show significant associations between case outcome and judicial characteristics. Likewise, individual courts and judges do not exhibit uniform tendencies to publish their opinions. Even after controlling for important case characteristics, some judges and courts are more likely to authorize publication than others. If these judges and courts also differ on their substantive results, as much research suggests, then the shape of precedent will be affected by seemingly neutral publication decisions. ${ }^{148}$

Our findings thus yield troubling public policy implications that make the constitutional issue posed by the Eighth Circuit more stark. We know that at least some unpublished decisions reach results with which other judges would disagree, and that judges and courts also vary in their tendency to publish outcomes. It follows that denying precedential value to unpublished opinions gives

147. Id. at 904 (quoting JOSEPH STORY, COMMENTARIES ON THE CONSTITUTION OF THE UNITED STATES $377-78$ (1833)).

148. As explained above, this pattern does not mean that judges or courts make stratogic decisions to manipulate precedent by publishing more or less of their opinions. Instead, judgos and courts may genuinely hold different attitudes toward the importance of publication. If thoso attitudes correlate with attitudes on judicial outcomes, however, then apparently noutral publication decisions will affect the direction of published precedents. 
judges discretion to decide which of their rulings will bind future decision-makers-and sets the stage for inconsistent treatment of like cases. Whether such a denial is consistent with the principle of "judicial Power" embedded in the Constitution awaits a definitive answer.

\section{CONCLUSION}

More than 25 years after the adoption of limited publication plans in the federal courts of appeals, controversy continues over the impact of those plans. For today's courts, some such plans seem essential. Without an increase in the number of sitting judges or a reduction in the courts' caseload, it is unimaginable that the courts could publish detailed deliberative opinions in every case they decide. ${ }^{149}$ The tension between limited publication and a tradition of precedential decision-making, however, warrants ongoing examination of publication decisions. ${ }^{150}$

Our investigation, using sophisticated empirical techniques, yields both reassurance and concern. The absence of strategic behavior, partisan publication decisions, or whistleblower effects suggests that panels generally pursue neutral criteria when deciding which opinions to publish. On the other hand, the substantial variation in publication rates among circuits resolving comparable claims under a single statute suggests that judges implement those criteria quite differently. The evidence of partisan disagreement among unpublished decisions, moreover, raises intriguing questions about the role of judicial attitudes in applying settled precedents.

Applying law, like shaping it, requires judgment; judgment implies discretion. Jurists and scholars have skirted the fact that many unpublished opinions, even those announcing no new principles of law, embody discretion. We should not expect mechanical justice from appellate judges, and it is unlikely that they perform rote duties in $80 \%$ of the cases they resolve. Exploring the role of discretion in unpublished opinions, as we have done here, can inform the administration of limited publication plans. That inquiry also expands our understanding of the ways in which appellate decision-making interweaves fact, principle, and discretion.

149. See Richard A. POSNer, THe Federal Courts: Challenge and Reform (1996); Richman \& Reynolds, supra note 34; Wald, supra note 2, at 1373.77.

150. Wald, supra note 2 , at 1376 (advocating "periodic overviews" of limited publication plans to assure that "arbitrary factors" do not "skew the system"). 
. 